\title{
Minnesota Multiphasic Personality InVentory 2 Recenze metody
}

\author{
AUTOŘI RECENZE: JITKA ČURDOVÁ ${ }^{1}$, MARTINA PouROVÁ ${ }^{1}$ \\ ${ }^{1}$ Katedra psychologie, Fakulta sociálních studií, Masarykova univerzita
}

\begin{tabular}{|l|l|}
\hline \multicolumn{1}{|c|}{ datum vzniku recenze: } & 27.11.2016 \\
\hline 1.1 název nástroje: & Minnesota Multiphasic Personality Inventory 2 \\
\hline \multicolumn{1}{|c|}{ zkrácený název: } & MMPI-2 \\
\hline 1.2 původní název: & Minnesota Multiphasic Personality Inventory 2 \\
\hline 1.4 autoři původního testu: & $\begin{array}{l}\text { James N. Butcher, John R. Graham, Yossef S. Ben-Porath, } \\
\text { Auke Tellegen, W. Grant Dahlstrom, Beverly Kaemmer }\end{array}$ \\
\hline 1.3 autoři lokální adaptace: & K. Netík, autor PC verze Z. Kojzar \\
\hline 1.7 lokální distributor: & Testcentrum \\
\hline $1.9 .1 / 1.9 .2$ datum vydání: & 2002 \\
\hline
\end{tabular}

\section{Obecné informace o metodě}

Minnesota Multiphasic Personality Inventory (dále jen MMPI) je širokospektrální testový nástroj sloužící ke zjištování vlastností osobnosti a psychických poruch. Uplatnění nalézá jak v klinické praxi, tak i v dalších oblastech psychologie coby screeningová metoda pro vyhledávání patologických rysů (například v personální psychologii $\mathrm{v}$ rámci výběrových řízení apod.) Cílovou skupinou jsou adolescenti a dospělá populace (Hogrefe-Testcentrum, 2016). Test původně vznikal pod názvem Minnesota Personality Schedule a jeho autory byli Hathaway a McKinley. Důvodem pro vytvoření dotazníku byla snaha o vyvinutí nástroje, který dokáže poskytnout komplexnější obraz vlastností respondenta než dotazníky $\mathrm{v}$ dané době dostupné (Hathaway \& McKinley, 1940). První verze MMPI byla publikována v roce 1942. Postupně byla rozšířena o čtvrtý indikátor validity, zvaný K škála zaměřující se na to, zda mají respondenti tendenci systematicky nadhodnocovat nebo podhodnocovat své potíže (Meehl \& Hathaway, 1946). Později byly také vytvořeny normy testu (Dahlstrom, Welsh \& Dahlstrom, 1972).

\footnotetext{
1 Masarykova univerzita, Fakulta sociálních studií, Katedra psychologie; Joštova 10, 60200 Brno.
} 
Z důvodu problematické formulace některých položek a důvodu kulturního a historického vývoje populace byl test revidován. Pro účely revize byla vytvořena výzkumná verze Form AX. Výsledná revidovaná verze inventáře MMPI-2 byla publikována roku 1989 (Hathaway \& McKinley, 2002). Finální verze dotazníku má 567 položek a oproti předchozí verzi obsahuje 10 nových doplňkových škál, 3 nové škály pro posouzení validity (VRIN, TRIN, Fb) a 15 nových obsahových škál (Greene, 2000). Celkově tedy MMPI2 obsahuje 123 škál z toho 14 je považováno za základní škály. Dále pak obsahuje ještě obsahové a doplňkové škály. Základní škály jsou jednak „Standardní klinické škály“ (patří sem hypochondrie, deprese, konverzní hysterie, psychopatická odchylka, maskulinita-feminita, paranoia, psychastenie, schizofrenie, hypomanie, sociální introverze), a za druhé pak „Validizační škály“, kam patří F škála (ukazatel málo frekventovaných odpovědí), indikátory defenzivity (L škála a F škála), S škála (škála mimořádně pozitivní sebeprezentace) a škála „nemohu říci“. Obsahové škály jsou úzkostnost, strachy, nutkavost, deprese, zájem o vlastní zdraví, bizarní psychické aktivity, zloba, cynismus, antisociální chování, chování typu A, nízká sebeúcta, sociální nepohoda, problémy v rodině, poruchy pracovního výkonu, negativní postoje k terapii. Doplňkové škály jsou pak Welshovy škály anxiety a potlačení (škála anxieta, škála potlačení, škála síla ega, škála dominance, škála sociální odpovědnost, škála rodové role), škály reflektující poruchy regulace chování (škála hostilita, škála nadměrná kontrola hostility, MacAndewova škála alkoholismu, škála manifestního návykového chování, škála návykového potenciálu), škály reflektující generalizovaný emocionální distress (škála vysokoškolská maladjustace, škála posttraumatická stresová porucha secundum Keane a Schlenger, škála distress v manželství), pět škál psychopatologie osobnosti (škála agresivita, škála psychoticismus, škála nedostatečná sebekontrola, škála negativní emocionalita, škála introverze)(Netík, 2002).

V současné době došlo k tvorbě alternativních klinických škál do restrukturovaných klinických škál (Hogrefe-Testcentrum, 2016; Tellegen et al, 2003; Doebbeling et al., 2005; Rogers et al., 2006; Shkalim, 2015). A to $\mathrm{z}$ důvodů vysoké interkorelace u standardních klinických škál (Tellegen et al, 2003; Doebbeling et al., 2005). Vylepšila se tak rozlišovací schopnost inventáře. $\mathrm{V}$ upraveném pojetí se tedy uvažuje o škálách: demoralizace, somatické stesky, nízké pozitivní emoce, cynismus, antisociální chování, perzekuční myšlenky, dysfunkční negativní emoce, abnormní prožitky, hypomanická aktivace a škála validity symptomu (Hogrefe-Testcentrum, 2016).

Při použití metody MMPI-2 se předpokládá supervidovaná a kontrolovaná administrace, tedy administrace pod kontrolou kvalifikovaného administrátora. V manuálu jsou jako předpoklady pro používání dotazníku znalost teorie používání psychologických testů minimálně na úrovni dokončeného magisterského studia jednooborové psychologie, znalosti psychologie osobnosti a psychopatologie. Pro vyplnění dotazníku je dále nutné připravit respondentovi adekvátní testové podmínky. Test je smysluplné administrovat pouze respondentům s přiměřenou schopností porozumět zadaným otázkám (Hathaway \& McKinley, 2002). 
Administrovat test je možné jak individuálně, tak skupinově, a lze použít metodu tužka/papír či vyplňovat test prostřednictvím počítače. U každé položky respondent vybírá z možností „souhlasím“ či „nesouhlasím“. Předpokládaná doba potřebná k administraci testu je 1-2 hodiny. Doba potřebná pro přepis záznamového archu do elektronické podoby je pak 10 minut (Hogrefe-Testcentrum, 2016).

\section{Skórování}

Test je vyhodnocován prostřednictvím počítačového programu a česká verze manuálu neobsahuje informace potřebné pro ruční skórování.

K převodu hrubých skórů na skóry standardizované jsou u jednotlivých klinických škál (Hs, D, Hy, Pd, Pa, Pt, Sc, Ma) a u obsahových škál využívány uniformní T-skóry, díky čemuž jsou korigovaná rozdílná rozložení hrubých skórů mezi jednotlivými škálami a pozitivní zešikmení hrubých skórů u standardizačního souboru (Netík, 2002). Převod hrubého skóre na uniformní T-skóry je kompromisem mezi lineární a standardizovanou transformací na T-skóry - řeší pozitivní zešikmení a zároveň se uniformní T-skóry blíží lineárním T-skórům. K převodu hrubého (lineárních T-skórů) na uniformní T-skóry byla použita polynomická regrese (Wang, 1992). Pro každou škálu existují dvě regresní rovnice, pro každé pohlaví jedna (Tellegen \& Ben-Porath, 1992). Pro základní škály (L, F, $\mathrm{K}, \mathrm{Mf}, \mathrm{Si}$ ) a pro všechny subškály a doplňkové škály jsou využívány lineární T-skóry (Netík, 2002).

Při skórování jsou zohledňovány i defenzivní postoje při vyplňování dotazníku, a to pomocí K škály, jejímiž autory jsou Meehl a Hathaway (1946). Prostřednictvím této škály se provádí K-korekce, která zvyšuje schopnost klinických škál diferencovat mezi kriteriálními a kontrolními skupinami. K-korekce se provádí přičtením konkrétního násobku hrubého skóru K-škály $\mathrm{k}$ hrubému skóru dané klinické škály. Např́klad Schizofrenii je korigována přičtením jednoho hrubého skóru K-škály (Stoklasa, 2012).

\section{Standardizace české verze MMPI-2}

Položky inventáře byly nezávisle přeloženy 2 jazykovými odborníky a 1 psychologem. Poté byla prvotní verze dotazníku konzultována 4 psychology a 1 odborníkem. Druhou verzi připomínkoval vydavatel. Počáteční soubor u standardizační studie byl zredukován o 215 osob (z původních 865) ze dvou důvodů. Prvním bylo nevyvážené rozložení skupin ve vztahu ke kritériím vzdělání a věk a druhým důvodem bylo, že někteří respondenti překročili maximální počet otázek, které mohly zůstat nezodpovězené, což je dle Amerických standardů 30 otázek, anebo dosáhli hrubého skóru vyššího než 20 což je kritická hodnota pro škály F a FB, které se zaměřují na odhalení neobvyklých a atypických odpovědí respondentů.

České normy byly vytvořeny na vzorku 650 osob, z toho bylo 325 mužů a 325 žen. Respondentů s dokončenou základní školou bylo 84, střední školou 211 a s vysokou školou 355. Počty respondentů v jednotlivých kategoriích však neodpovídají rozložení v české populaci. S ohledem na data českého statistického úřadu z roku 2016 by při zachování stejné velikosti standardizačního souboru měly být normy tvořeny na 121 
lidech s nejvyšším dosaženým základním vzděláním, 430 lidech s dokončenou střední školou a 99 participantech s absolvovanou vysokou školou. Vzniká zde poněkud výrazný nepoměr, nelze se však domnívat, že by v roce 2002, kdy bylo MMPI-2 publikováno, byly statistiky výrazně odlišné od dat uvedených ČSÚ z roku 2016. Věk respondentů byl mezi 18-60 lety $(M=31 ; S D=9,3)$. Výpočet norem pro českou verzi respektoval principy verze americké (Hathaway \& McKinley, 2002).

MMPI-2 v české verzi nemá normy rozdělené pro jednotlivé věkové kategorie respondentů, a ani podle jiného kritéria. Tvorba norem pro odlišné věkové skupiny a zaměření se na jejich odlišné hodnoty skórů je přitom předpokladem pro lepší přilnavost norem pro testovanou populaci. Cicchetti (1994) uvádí, že tvorba norem pro odlišné věkové kategorie může reflektovat přirozené odlišnosti během vývoje jedince. Díky věkovým normám lze maladaptivní chování jedince porovnat s jeho vrstevníky a lépe tak posoudit jím dosažený skór. Pokud však budeme porovnávat s celonárodním průměrem získaným ze všech věkových kategorií, může být standardizovaný skór nepřiléhavý (Cicchetti, 1994). Domníváme se proto, že by bylo velmi výhodné pro MMPI2 vytvořit normy založené na diferenciovaných věkových kategoriích. Jedním z důvodů proč, by byly normy výhodné, je fakt, že MMPI-2 obsahuje klinické škály, které se odkazují k duševním nemocem, jež můžeme popsat třeba skrze MKN-10 a jejichž prodromální fáze a první ataky bývají velmi často vztahovány k určitému věku člověka.

\section{Psychometrické vlastnosti škál}

\section{Validita}

O validitě jako takové se autoři zmiňují velmi zběžně. Na webových stránkách HogrefeTestcentrum (2016) je uvedeno, že byly provedeny validizační studie porovnávající zdravé osoby s vybranými skupinami pacientů, konkrétní výsledky pro české normy však v manuálu nejsou uvedeny (Hogrefe-Testcentrum, 2016). Autoři dále neuvádí informace o vztahu výsledků jednotlivých škál a testů měřících podobné konstrukty. U klinických škál nejsou uvedeny informace o souběžné validitě.

Pro českou verzi dotazníku byly provedeny analýzy porovnávající faktorovou strukturu klinických škál $\mathrm{v}$ českém a zahraničním (americkém a německém) normativním souboru. Korelace klinických škál byly v dobré shodě se zahraničními studiemi. Dále byla provedena analýza hlavních komponent s rotací Varimax. Faktorové struktury v německé a české studii jsou prezentovány jako srovnatelné, korelační matice a údaje o faktorové struktuře základních škál jsou uvedeny v manuálu, autoři však uvádí, že faktorová analýza klinických škál je metodicky pochybná z důvodu překrývání některých položek (Hogrefe-Testcentrum, 2016). Čtenář manuálu si však jen stěží může vytvořit pravdivý obrázek o srovnatelnosti faktorových struktur zahraniční i naší standardizační studie, nebot' zde není uvedeno dostatečné množství informací, které by podpořily rozhodnutí. Například zde chybí údaje o demografických a dalších charakteristikách zahraničních studií či samotné rozložení dat. Slovo „srovnatelné“ 
neposkytuje žádné bližší informace, které souvisí s případnými konkrétními odlišnostmi faktorové struktury klinických škál, potažmo i samotného standardizačního souboru.

\section{Reliabilita}

Reliabilita klinických škál je určená pouze pro původní (americký) standardizační soubor a to test-retest reliabilitou, která nabývá hodnot v intervalu 0,7-0,93 u mužů a 0,54-0,92 u žen. Pro klinickou škálu 1 (hypochondrie) byl koeficient test-retest reliability pro přibližně týdenní odstup měření 0,85 u mužů i u žen, u dalších škál nebyly konkrétní hodnoty test-retest reliability uvedeny stejně jako časový odstup při testování. Vnitřní konzistence určená Cronbachovou $\alpha$ pro klinické škály je v rozmezí 0,77-0,91 u mužů a 0,78-0,91 u žen.

Reliability škál byly počítány během restandardizačních studií a konkrétní hodnoty pro jednotlivé škály jsou uvedeny pouze v manuálu Butcher et al. (2001), na který se manuál odkazuje (Netík, 2002). Během české standardizační studie nebyly hodnoty reliability pro jednotlivé škály přepočítány. V manuálu dále nejsou uvedeny intervaly spolehlivosti pro jednotlivé škály.

\section{Shrnutí a zhodnocení metody}

MMPI-2 je metoda, která má přinést komplexní pohled na osobnost člověka. Je primárně určená pro využívání v diagnostice a klinické praxi. V současnosti se však hojně využívá i $\mathrm{v}$ jiných oblastech, například $\mathrm{v}$ psychologii organizace, při výběrových řízeních atd. $\mathrm{V}$ České republice je metoda oblíbeným a hojně využívaným nástrojem i přes mnoho chybějících relevantních informací a otazníků, které se objevují při bližším zkoumáním metody. Nutno však podotknout, že minimálně $\mathrm{v}$ zahraničí dochází $\mathrm{k}$ tvorbě restandardizačních studí a dalšímu následnému vylepšování metody. Jako příklad by se dalo uvést, že $\mathrm{v}$ reakci na častou připomínku ohledně vysoké heterogenity škál a překrývání konceptů (viz v Doebbeling et al., 2005), které škály měří, došlo k restrukturaci klinických škál.

Za metodou nestojí žádná konkrétní teorie, jde pouze o názorovou shodu odborníků, kdy bylo předpokládáno, že komplexnější metoda, která bude měřit mnoho konstruktů na relativně malém počtu položek, bude užitečnější, než mnoho specifických testů. Výhodou takového testu by mělo být zejména vytváření norem pro více konstruktů na jedné populaci, což by mohlo zjednodušit interpretaci a umožnit lepší srovnávání jednotlivých skórů (Hathaway \& McKinley, 1940).

Manuál se velmi detailně věnuje interpretaci jednotlivých škál a popisuje ji smysluplně, avšak mnoho jiných důležitých informací pro posouzení vhodnosti metody v něm chybí. Například detailní popis reliability jednotlivých škál, popis validity, nebo popis tvorby jednotlivých položek.

Také tvorbu norem lze považovat za problematickou. Při tvorbě norem pro Českou republiku byl použit velmi malý standardizační vzorek, který je vzhledem k míře používání metody možné považovat za nedostatečný. Dále zde nejsou informace o 
férovosti položek k menšinám žijícím v ČR (tím se ale nezabýval ani Americký manuál). Další nevýhodou této metody je absence transparentnosti celého procesu vyhodnocování testu. Vyhodnocovací program je sice uživatelsky př́ijemný, ale chybí zde mnoho vhodných informací pro výslednou interpretaci (např. intervaly spolehlivosti pro výsledné skóry).

Současný stav inventáře by bylo vhodné podrobit bližšímu výzkumnému šetření se zaměřením se na popis reliability škál a validity celé metody. $Z$ výše uvedených důvodů by se měla zvážit revize inventáře.

\section{Zdroje}

Butcher, J. N. (2001). Minnesota Multiphasic Personality Inventory (MMPI).

Cicchetti, D. V. (1994). Guidelines, Criteria, and Rulez of Thumb for Evaluating Normed and Standardized Assessment Instruments in Psychology. Psychological Assessment, 6(4), s. 284-290.

Doebbeling, B. N., Simms, L. J., Casillas, A., Clark, L. A., \& Watson, D. (2005). Psychometric Evaluation of the Restructed Clinical Scales of the MMPI-2. Psychological Assessment, 17 (3), s. 345-358.

Dahlstrom, W. G., Welsh, G. S., \& Dahlstrom, L. E. (1972). An MMPI handbook: I. Clinical interpretation.(Rev.)

Greene, R. L. (2000). The MMPI-2: An interpretive manual . Allyn \& Bacon.

Hathaway, S. R., \& McKinley, J. C. (1940). A multiphasic personality schedule (Minnesota): I. Construction of the schedule. The Journal of Psychology, 10(2), s. 249-254.

Hathaway, S.R. \& McKinley, J.C. (2002). [Autor české verze testu: Netík, K.] MMPI 2: Minnesota Multiphasic Personality Inventory-2. Praha: Testcentrum

Hogrefe-Testcentrum. (2016). MMPI®-2 - Minnesota Multiphasic Personality Inventory®-2. Dostupné online 27.11.2016 na http://www.testcentrum.com/testy/mmpi-2

Meehl, P. E., \& Hathaway, S. R. (1946). The K factor as a suppressor variable in the Minnesota Multiphasic Personality Inventory. Journal of Applied Psychology, 30(5), s. 525.

Netík, K. (2002). The Minnesota Multiphasic Personality Inventory - 2: první české vydání. Praha: Testcentrum

Obyvatelstvo ve věku 15 a více let podle nejvyššího ukončeného vzdělání ve správních obvodech ORP. (2016). [Online]. Retrieved March 11, 2017, from https://vdb.czso.cz/vdbvo2/faces/cs/index.jsf?page=vystup-objekt-

vyhledavani\&vyhltext=vzd\%C4\%9Bl\%C3\%A1n\%C3\%AD\&bkvt=dnpkxJtsw6Fuw60.\&katal og=all\&pvo=SLD9060PU-OR

Rogers, R., Sewell, K. W., \& Salekin, R. T. (1994). A Meta-Analysis of Malingering on the MMPI-2. Assessment, 1(3), s. 227-237.

Rogers, R., Sewell, K. W., Harrison, K. S., \& Jordan, M. J. (2006). The MMPI-2 Restructured Clinical Scales: A Paradigmatic Shift in Scale Development. Journal of personality assessment, 87 (2), s. 139-147.

Shkalim, E. (2015). Psychometric Evaluation of the MMPI-2/MMPI-2-RF Restructured Clinical Scales in an Israeli Sample. Assessment, 22 (5), s. 607-618. 
Stoklasa, J. (2012). Fuzzy přístup k vyhodnocování osobnostního inventáře MMPI-2 (Diplomová práce). Olomouc.

Tellegen, A., \& Ben-Porath, Y. S. (1992). The new uniform T scores for the MMPI-2: Rationale, derivation, and appraisal. Psychological Assessment, 4(2), s. 145.

Tellegen, A., Ben-Porath, Y. S., McNulty, J. L., Arbisi, P. A., Graham, J. R., \& Kaemmer, B. (2003). The MMPI-2 restructured clinical (RC) scales: Development, validation, and interpretation. Minneapolis, MN: University of Minnesota Press.

Wang, J. J. (1992). An Analytical Approach to Generating Norms for Skewed Normative Distributions. 


\section{MODEL RECENZE PODLE EFPA PRO POPIS \\ A HODNOCENÍ PSYCHOLOGICKÝCH TESTŮ \\ FORMULÁŘ RECENZE TESTU A POZNÁMKY PRO \\ RECENZENTY ${ }^{1}$}

Toto je lokální úprava dokumentu pro účely publikace v časopise Testfórum.

Originální český překlad je $\mathrm{k}$ dispozici na stránkách EFPA

(www.efpa.eu/download/505cd9db4144ecb16174087909c9cd6d).

Původní verzi sestavil a uspořádal Dave Bartram

Doplnili a revidovali Patricia Lindley, Dave Bartram a Natalie Kennedy v dubnu $2004^{2}$

Současná verze 3.42: květen 2005

Český překlad: Tomáš Urbánek

Od uživatelů tohoto dokumentu a jeho obsahu žádá EFPA, aby uznali tento zdroj prostřednictvím následujícího textu:

"Kritéria pro recenzi testu podle EFPA do značné míry vychází z formy a obsahu kritérií pro recenze testů Britské psychologické společnosti (BPS) a kritérií vytvořených Komisí pro testové záležitosti (COTAN) Holandské asociace psychologů (NIP). Dave Bartram a Patricia Lindley původně vyvinuli kritéria BPS a recenzní procedury pro UK Employment Service a později rozširrili jejich používání pro celou BPS. Arne Evers připravil k vydání nizozemský system posuzování kvality testů.

EFPA je vděčná BPS a NIP za svolení použít jejich kritéria jako základ pro vytvoření evropského modelu. EFPA je také vděčná Davu Bartramovi, Arnu Eversovi a Patricii Lindley za jejich přispění k vývoji tohoto modelu. Veškerá intelektuální vlastnická práva původních kritérií podle BPS a NIP jsou nadále uznávána a náleží těmto orgánům."

\footnotetext{
1 Tento dokument byl vytvořen z několika zdrojů, včetně Hodnotícího formuláře pro recenzi testu používaného v BPS (NPAL a Řídící komise pro testové standardy při BPS - Steering Committee on Test Standards), Španělského dotazníku pro hodnocení psychometrických testů (Španělská psychologická asociace) a Systému pro posuzování kvality testu (Komise pro testování Holandské asociace psychologů). Některé části byly adaptovány se svolením z dokumentu: BPS Books Reviews of Level B Assessment Instruments for use in Occupational Assessment, Notes for Reviewers: Version 3.1. December 1998: Copyright (C) NPAL, 1989, 1993, 1998.

2 Současná verze je spojením dvou oddělených dokumentů (Formuláře recenze a Poznámek pro recenzenty). Obsah byl navíc uspořádán a doplněn na základě jeho používání recenzenty online testů v BPS.
} 


\section{Část 1:}

Popis nástroje: Obecné informace a klasifikace

\begin{tabular}{|c|c|c|}
\hline . & Recenzent 1: & Jitka Čurdová \\
\hline & Recenzent 2: & Martina Pourová \\
\hline & Konzultující editor: & Mgr. Hynek Cígler, Ph.D. \\
\hline & Vedoucí editor: & Mgr. Hynek Cígler, Ph.D. \\
\hline & $\begin{array}{l}\text { Vedoucí editor aktualizace: } \\
\text { (pouze v případě aktualizací) }\end{array}$ & \\
\hline & $\begin{array}{l}\text { Editor aktualizace: } \\
\text { (pouze v př́padě aktualizací) }\end{array}$ & \\
\hline & Datum vzniku této recenze: & 27. 11.2016 \\
\hline \multirow[t]{2}{*}{1.1} & Název nástroje (lokální verze): & $\begin{array}{l}\text { Minnesota Multiphasic Personality } \\
\text { Inventory } 2\end{array}$ \\
\hline & Zkrácená verze názvu testu: & MMPI-2 \\
\hline 1.2 & $\begin{array}{l}\text { Původní název testu (pokud je lokální } \\
\text { verze adaptací): }\end{array}$ & \\
\hline 1.4 & Autoři původního testu: & $\begin{array}{l}\text { James N. Butcher, John R. Graham, } \\
\text { Yossef S. Ben-Porath, Auke Tellegen, } \\
\text { W. Grant Dahlstrom and Beverly } \\
\text { Kaemmer }\end{array}$ \\
\hline 1.3 & Autoři lokální adaptace: & K. Netík, autor PC verze Z. Kojzar \\
\hline 1.7 & Lokální distributor/vydavatel testu: & Testcentrum \\
\hline 1.8 & $\begin{array}{l}\text { Vydavatel původní verze testu (pokud je } \\
\text { jiný než současný distributor/vydavatel): }\end{array}$ & University of Minnesota \\
\hline 1.9 .1 & Datum vydání současné revize/vydání: & \\
\hline 1.9 .2 & $\begin{array}{l}\text { Datum vydání adaptace pro lokální } \\
\text { užívání: }\end{array}$ & 2002 \\
\hline 1.9 .3 & Datum vydání původního testu: & 1989 \\
\hline
\end{tabular}




\section{Obecný popis nástroje}

Minnesota Multiphasic Personality Inventory (dále jen MMPI) je širokospektrální testový nástroj sloužící ke zjišt'ování vlastností osobnosti a psychických poruch. Uplatnění nalézá jak v klinické praxi, tak i v dalších oblastech psychologie coby screeningová metoda pro vyhledávání patologických rysů (např́klad v personální psychologii $\mathrm{v}$ rámci výběrových řízení apod.) Cílovou skupinou jsou adolescenti a dospělá populace (Hogrefe-Testcentrum, 2016). Test původně vznikal pod názvem Minnesota Personality Schedule a jeho autory byli Hathaway a McKinley. Důvodem pro vytvoření dotazníku byla snaha o vyvinutí nástroje, který dokáže poskytnout komplexnější obraz vlastností respondenta než dotazníky v dané době dostupné (Hathaway \& McKinley, 1940). První verze MMPI byla publikována v roce 1942. Postupně byla rozšířena o čtvrtý indikátor validity, zvaný $\mathrm{K}$ škála zaměřující se na to, zda mají respondenti tendenci systematicky nadhodnocovat nebo podhodnocovat své potíže (Meehl \& Hathaway, 1946). Později byly také vytvořeny normy testu (Dahlstrom, Welsh \& Dahlstrom, 1972).

$\mathrm{Z}$ důvodu problematické formulace některých položek a důvodu kulturního a historického vývoje populace byl test revidován. Pro účely revize byla vytvořena výzkumná verze Form $A X$. Výsledná revidovaná verze inventáre MMPI-2 byla publikována roku 1989 (Hathaway \& McKinley, 2002). Finální verze dotazníku má 567 položek a oproti předchozí verzi obsahuje 10 nových doplňkových škál, 3 nové škály pro posouzení validity (VRIN, TRIN, Fb) a 15 nových obsahových škál (Greene, 2000).

Celkově tedy MMPI2 obsahuje 123 škál z toho 14 je považováno za základní škály. Dále pak obsahuje ještě obsahové a doplňkové škály. Základní škály jsou jednak „Standardní klinické škály“ (patří sem hypochondrie, deprese, konverzní hysterie, psychopatická odchylka, maskulinita-feminita, paranoia, psychastenie, schizofrenie, hypomanie, sociální introverze), a za druhé pak „Validizační škály“, kam patří F škála (ukazatel málo frekventovaných odpovědí), indikátory defenzivity (L škála a F škála), S škála (škála mimořádně pozitivní sebeprezentace) a škála „nemohu říci“. Obsahové škály jsou úzkostnost, strachy, nutkavost, deprese, zájem o vlastní zdraví, bizarní psychické aktivity, zloba, cynismus, antisociální chování, chování typu A, nízká sebeúcta, sociální nepohoda, problémy v rodině, poruchy pracovního výkonu, negativní postoje k terapii. Doplňkové škály jsou pak Welshovy škály anxiety a potlačení (škála anxieta, škála potlačení, škála síla ega, škála dominance, škála sociální odpovědnost, škála rodové role), škály reflektující poruchy regulace chování (škála hostilita, škála nadměrná kontrola hostility, MacAndewova škála alkoholismu, škála manifestního návykového chování, škála návykového potenciálu), škály reflektující generalizovaný emocionální distress (škála vysokoškolská maladjustace, škála posttraumatická stresová porucha secundum Keane a Schlenger, škála distress v manželství), pět škál psychopatologie osobnosti (škála agresivita, škála psychoticismus, škála nedostatečná sebekontrola, škála negativní emocionalita, škála introverze) (Netík, 2002). Při použití metody MMPI-2 se předpokládá supervidovaná a kontrolovaná administrace, tedy administrace pod kontrolou kvalifikovaného administrátora. V manuálu jsou jako předpoklady pro používání dotazníku znalost teorie použivání psychologických testů minimálně na úrovni dokončeného magisterského studia jednooborové psychologie, znalosti psychologie osobnosti a psychopatologie. Pro vyplnění dotazníku je dále nutné připravit respondentovi adekvátní testové podmínky. Test je smysluplné administrovat pouze respondentům s přiměřenou schopností porozumět zadaným otázkám (Hathaway \& McKinley, 2002).

Administrovat test je možné jak individuálně, tak skupinově, a lze použít metodu tužka/papír či vyplňovat test prostřednictvím počítače. U každé položky respondent vybírá z možností „souhlasím“ či „nesouhlasím“. Předpokládaná doba potřebná k administraci testu je 1-2 hodiny. Doba potřebná pro přepis záznamového archu do elektronické podoby je pak 10 minut (Hogrefe-Testcentrum, 2016). 


\section{Část 2:}

\section{Klasifikace}

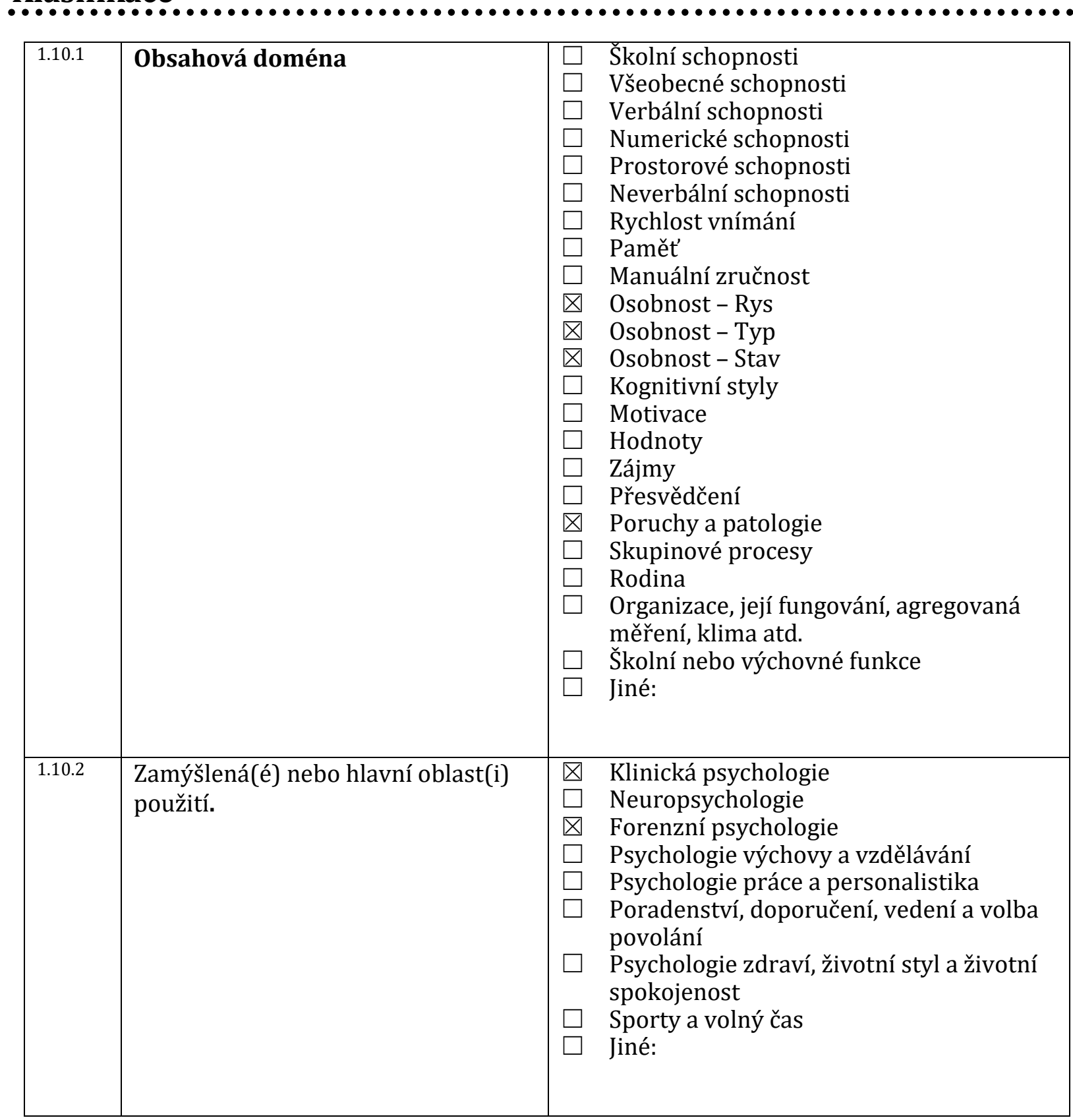




\begin{tabular}{|c|c|c|}
\hline 1.10 .3 & $\begin{array}{l}\text { Zamýšlený způsob použití } \\
\text { (podmínky, za jakých byl nástroj } \\
\text { standardizován a validizován) }\end{array}$ & 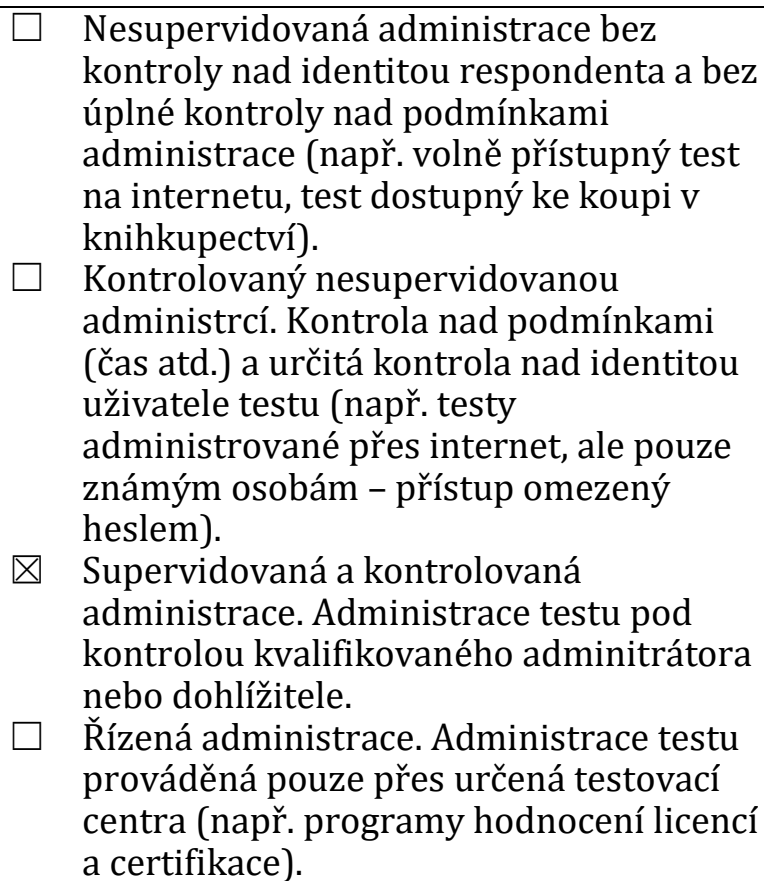 \\
\hline 1.10 .4 & $\begin{array}{l}\text { Popis populací, pro které je test } \\
\text { určen: }\end{array}$ & Dospělá populace a adolescenti \\
\hline
\end{tabular}




\begin{tabular}{|c|c|c|}
\hline 1.10 .5 & $\begin{array}{l}\text { Počet škál a krátký popis } \\
\text { proměnné nebo proměnných } \\
\text { měřených nástrojem }\end{array}$ & $\begin{array}{l}\text { MMPI-2 obsahuje } 123 \text { škál, z toho } 14 \text { je } \\
\text { považováno za základní škály, dále pak ještě } \\
\text { obsahové a doplňkové škály. } \\
\text { Standardní klinické škály: } \\
\text { Hypochondrie, deprese, konverzní hysterie, } \\
\text { psychopatická odchylka, maskulinita- } \\
\text { feminita, paranoia, psychastenie, schizofrenie, } \\
\text { hypomanie, sociální introverze. } \\
\text { Validizační škály: } \\
\text { Ukazatel nekonzistentnost odpovědi, škála } \\
\text { „nemohu říct“, F škála (ukazatel málo } \\
\text { frekventovaných odpovědí), indikátory } \\
\text { defenzivity (L škála a F škála), S škála (škála } \\
\text { mimořádně pozitivní sebeprezentace) } \\
\text { Obsahové škály: } \\
\text { Úzkostnost, strachy, nutkavost, deprese, } \\
\text { zájem o vlastní zdraví, bizadrní psychiské } \\
\text { aktivity, zloba, cynismus, antisociální chování, } \\
\text { chování typu A, nízá sebeúcta, sociální } \\
\text { nepohoda, problémy v rodině, poruchy } \\
\text { pracovního výkonu, negativní postoje } \\
\text { k terapii }\end{array}$ \\
\hline
\end{tabular}




\begin{tabular}{|c|c|c|}
\hline 1.11 & Formát položek & $\begin{array}{ll}\square & \text { Otevřený } \\
\square & \text { Mnohonásobná volba, alternativy na } \\
& \text { stejné škále } \\
\square & \text { Bipolární adjektiva } \\
\square & \text { Likertovy ratingy (škály) } \\
\square & \text { Nucená volba, alternativy na smíšených } \\
\text { škálách (ipsativní) - vysvětlení viz } \\
\text { Poznámky } \\
\square \quad \text { Mnohonásobná volba, alternativy na } \\
\text { smíšených škálách (ipsativní) - } \\
\text { vysvětlení viz Poznámky } \\
\square \text { Sady párů adjektiv (sémantický } \\
\text { diferenciál), smíšené škály (ipsativní) } \\
\square \quad \text { Jiné: } \\
\quad \text { Dichotomická volba: souhlas x } \\
\text { nesouhlas }\end{array}$ \\
\hline 1.12 & Počet položek testu: & $\begin{array}{l}\text { Test obsahuje } 567 \text { položek, vždy jde o výrok, } \\
\text { se kterým respondent vyjadřuje souhlas či } \\
\text { nesouhlas. }\end{array}$ \\
\hline 1.13 & Způsob(y) administrace: & $\begin{array}{ll}\bigotimes & \text { Interaktivní individuální administrace } \\
\bigotimes & \text { Supervidovaná skupinová administrace } \\
\bigotimes & \text { Počítačová lokálně nainstalovaná } \\
\text { aplikace - pod supervizí/dohledem } \\
\square & \text { Počítačová aplikace na webu - pod } \\
\text { supervizí/dohledem } \\
\square \\
\text { Počítačová lokálně nainstalovaná } \\
\text { aplikace - bez supervise/testování sebe } \\
\square \\
\text { Počítačová aplikace na webu - bez } \\
\text { supervize/testování sebe } \\
\square \text { Jiné: }\end{array}$ \\
\hline 1.14 & Způsob odpovídání: & $\begin{array}{ll}\square & \text { Ústní rozhovor } \\
\bigotimes & \text { Papír a tužka } \\
\square & \text { Manuální operace } \\
\bigotimes & \text { Na počítači } \\
\square & \text { Jiné: }\end{array}$ \\
\hline
\end{tabular}




\begin{tabular}{|c|c|c|}
\hline 1.15 & $\begin{array}{l}\text { Čas potřebný pro administraci } \\
\text { nástroje: } \\
\text { Čas na př́ípravu (čas, který zabere } \\
\text { administrátorovi připravit a rozložit } \\
\text { materiály pro diagnostické sezení). } \\
\text { - Čas na administraci na sezení: zahrnuje } \\
\text { čas potřebný pro dokončení všech } \\
\text { položek a odhad času potřebného pro } \\
\text { podání instrukcí, projití zácvičných } \\
\text { položek a nějaké doplňující komentáře } \\
\text { na konci sezení. } \\
\text { - Skórování: čas nutný pro získání } \\
\text { hrubých skórun. } \\
\text { Analýza: čas strávený prováděním } \\
\text { dalších prací s hrubýmí skóry, aby se z } \\
\text { nich odvodily další míry a zformulovala } \\
\text { rozumně úplná interpretace (za } \\
\text { předpokladu, že znáte nástroj). } \\
\text { Zpětná vazba: čas potřebný k př́pravě a } \\
\text { poskytnutí zpětné vazny vyšetřované } \\
\text { osobě. } \\
\text { Připouští se, že čas posledních dvou } \\
\text { komponent se může značně lišit - v závislosti } \\
\text { na kontextu, ve kterém se nástroj používá. } \\
\text { Ale aspoň nějaké údaje a komentáře budou } \\
\text { užitečné. }\end{array}$ & 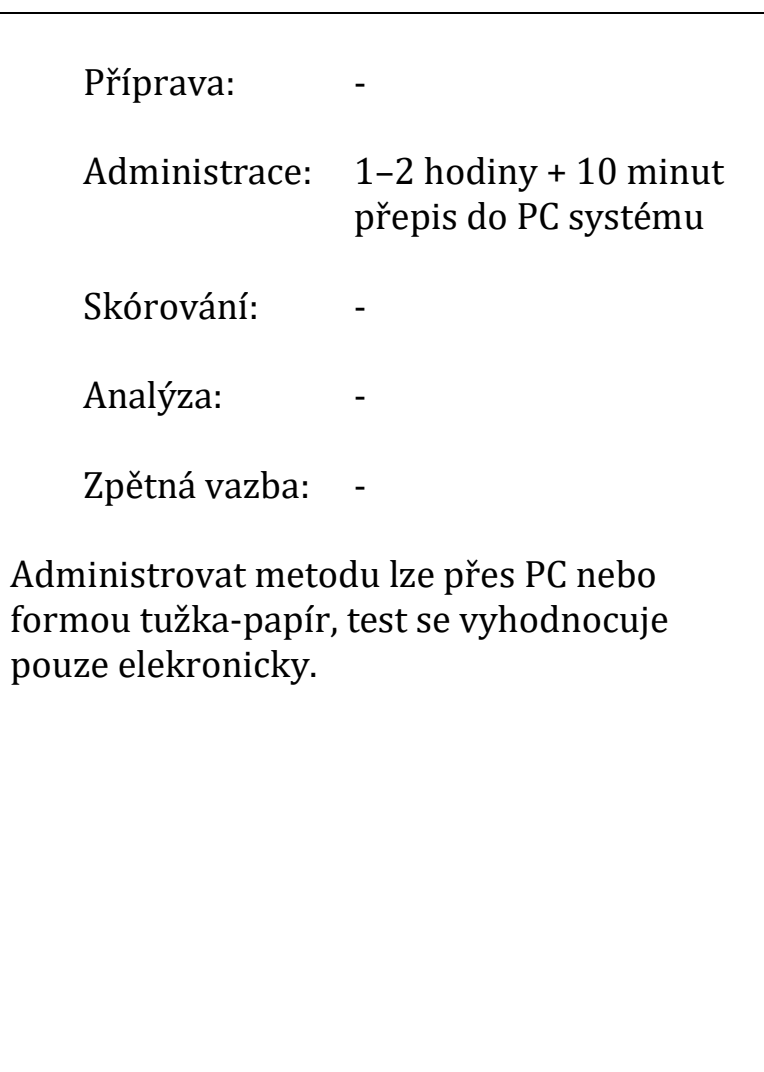 \\
\hline 1.16 & $\begin{array}{l}\text { Jsou k dispozici různé formy } \\
\text { nástroje? }\end{array}$ & $\begin{array}{l}\text { MMPI-2 nemá více verzí dotazníku. } \\
\text { Administrovat jej však lze dvěma způsoby } \\
\text { a to před PC nebo formou tužka-papír, } \\
\text { vždy však jde o stejnou verzi téhož } \\
\text { dotazníku. }\end{array}$ \\
\hline
\end{tabular}

\section{Č́ást 3:}

\section{Měření a skórování}

\begin{tabular}{|c|c|c|}
\hline 1.17 & Procedura skórování testu: & 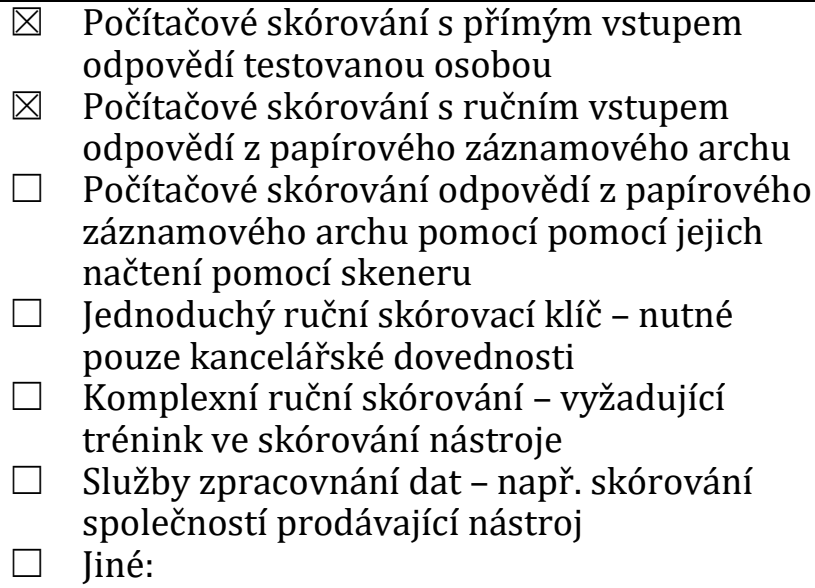 \\
\hline
\end{tabular}




\begin{tabular}{|c|c|c|}
\hline 1.18 & Skóry: & $\begin{array}{l}\text { Systém skórvání je komplexní. Metoda pracuje } \\
\text { s hrubými skóry a převod na vážené skóry (T- } \\
\text { skóre). Škály na určení přijatelnsoti protokolu } \\
\text { pak využívají k-korelace či indexy (index F-K). } \\
\text { Na základě výsledných skórů pak dochází } \\
\text { k tvorbě validizačních, klinických a kódových } \\
\text { profilů u posuzovnané osoby. }\end{array}$ \\
\hline 1.19 & $\begin{array}{l}\text { Transformace skóru na standardní } \\
\text { skóry: }\end{array}$ & $\begin{array}{ll}\square & \text { Normalizovaná - skóry se získají použitím } \\
\text { normalizační tabulky } \\
\square \\
\text { Nenormalizovaná - skóry se získají lineární } \\
\text { transformací }\end{array}$ \\
\hline 1.20 & Použité škály & 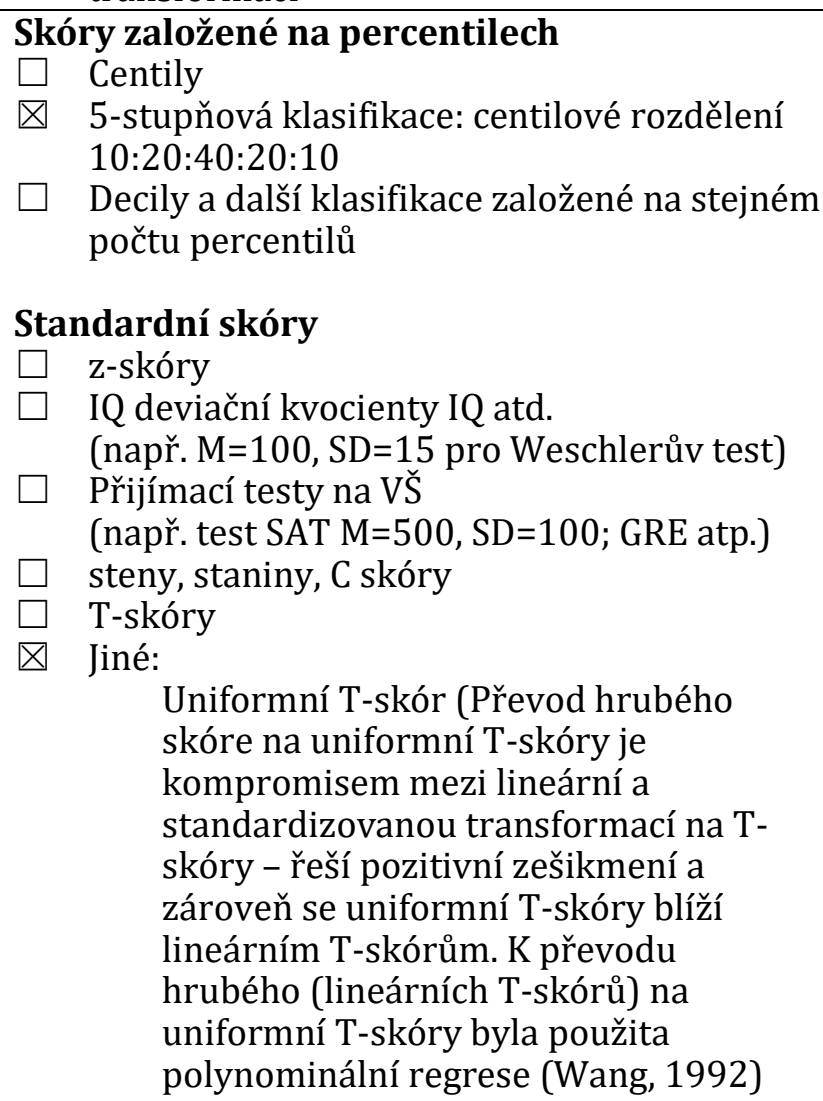 \\
\hline
\end{tabular}

\section{Č́st 4:}

\section{Počítačově generované zprávy}

Toto je čistě popisné. Hodnocení zpráv bude součástí části recenze nazvané Hodnocení.

\begin{tabular}{|l|l|ll|}
\hline 1.21 & $\begin{array}{l}\text { Jsou počítačově generované zprávy } \mathbf{k} \\
\text { dispozici s nástrojem? }\end{array}$ & $\bigotimes \quad$ Ano \\
$\square \mathrm{Ne}$ \\
\hline
\end{tabular}

\begin{tabular}{|l|l|l|}
\hline 1.21 .0 & Název nebo popis zprávy: & MMPI-2 \\
\hline
\end{tabular}




\begin{tabular}{|c|c|c|c|}
\hline 1.21 .1 & $\begin{array}{l}\text { Média: } \\
\text { Zprávy mohou sestáaat pouze z textu nebo obsahovat } \\
\text { text spolu s grafickými nebo tabulkovými zobrazeními } \\
\text { skórù (napřs stenovými profily). Kde jsou prezentovány } \\
\text { text i data, mohou být prezentovány prostě paralelně, } \\
\text { nebo mohou být propojeny, takže vztah mezi textovými } \\
\text { výroky a skóry je explicitně vyjádřen. }\end{array}$ & $\begin{array}{l}\square \\
\square\end{array}$ & $\begin{array}{l}\text { Pouze text } \\
\text { Text a grafika bez vzájemného vztahu } \\
\text { Integrovaný text a grafika }\end{array}$ \\
\hline 1.21 .2 & $\begin{array}{l}\text { Komplexnost: } \\
\text { Některé zprávy jsou velmi jednoduché, např. pouze } \\
\text { nahrazují kusem textu stenový skór v popisech } \\
\text { jednotlivých škál. Jiné jsou komplexnějsís, zahrnujíć č́ásti } \\
\text { textu, které jou ve vztahu ke vzorcum nebo } \\
\text { konfiguracím skórú škál a které berou v úvahu vliv } \\
\text { interakcí škál. }\end{array}$ & $\square$ & $\begin{array}{l}\text { Jednoduchá (Například seznam odstavců } \\
\text { podávajících popisy škál) } \\
\text { Střední (Směs jednoduchých popisů a } \\
\text { několika popisů konfigurací) } \\
\text { Komplexní (Obsahuje popisy vzorců a } \\
\text { konfigurací skórů škál a interakce škál) }\end{array}$ \\
\hline 1.21 .3 & $\begin{array}{l}\text { Struktura zprávy: } \\
\text { Struktura má vztah ke komplexitě. }\end{array}$ & $\square$ & $\begin{array}{l}\text { Založená na škálách (kde je zpráva } \\
\text { postavena na jednotlivých škálách) } \\
\text { Založená na faktorech (kde je zpráva } \\
\text { zkonstruována na základě faktorů vyššího } \\
\text { rádu - jako je "Big Five" pro měření } \\
\text { osobnosti). } \\
\text { Založená na konstruktech - kde je zpráva } \\
\text { postavena kolem jednoho nebo vice sad } \\
\text { konstruktů (např. v pracovním prostředí by } \\
\text { to mohly být takové jako typy týmů. styly } \\
\text { vedení, tolerance vǔči stresu atd.), které jsou } \\
\text { spojeny s původními skóry škál. } \\
\text { Založená na kritériu, kde se zpráva soustředí } \\
\text { na souvislosti s empirickými výstupy (např. } \\
\text { tréninkový potenciál, pracovní výkon, } \\
\text { absentérství atd.). } \\
\text { Jiná: }\end{array}$ \\
\hline 1.21 .4 & 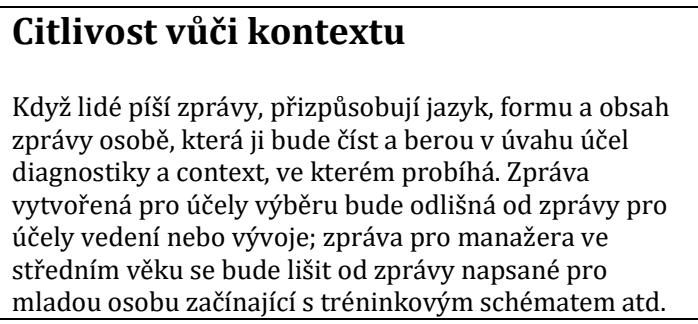 & $\begin{array}{l}\otimes \\
\square\end{array}$ & $\begin{array}{l}\text { Jedna verze pro všechny kontexty } \\
\text { Předdefinované verze pro různé kontexty } \\
\text { Uživatelem definovatelné kontexty } \\
\text { a editovatelné zprávy }\end{array}$ \\
\hline 1.21 .5 & $\begin{array}{l}\text { Klinická-pravděpodobnostní } \\
\text { Většina systémů zpráv je založena na klinickém úsudku. } \\
\text { To znamená, jeden nebo vice lidí, kteř́í jsou “expertní } \\
\text { uživatelée" daného nástroje, napsali cásti textu. Zprávy } \\
\text { tedy budou obsahovat jejich zvláštní interpretace škál. } \\
\text { Některé systémy obsahují pravděpodobnostní zprávy, } \\
\text { kde jsou tvrzení založena na empirických validizačních } \\
\text { studiích spojujících skóry škál napřs. s mírami pracovního } \\
\text { výkonu. }\end{array}$ & $\square$ & $\begin{array}{l}\text { Založena na klinickém úsudku jednoho } \\
\text { experta } \\
\text { Založena na } \\
\text { empirických/pravděpodobnostních vztazích } \\
\text { Založena na klinických úsudcích skupiny } \\
\text { expertů }\end{array}$ \\
\hline
\end{tabular}




\begin{tabular}{|c|c|c|c|}
\hline 1.21 .6 & $\begin{array}{l}\text { Modifikovatelnost } \\
\text { Výstup zprávy je často fixní. Ale některé systémy vytvoří } \\
\text { výstup ve formě souboru, který může uživatel dale } \\
\text { zpracovat. }\end{array}$ & $\begin{array}{l}\square \\
\square\end{array}$ & $\begin{array}{l}\text { Nemodifikovatelná (pouze fixní tištěný } \\
\text { výstup) } \\
\text { Omezené modifikace (omezené na určité } \\
\text { oblasti, např. pole biografických dat) } \\
\text { Neomezené modifikace (např. díky přístupu } \\
\text { k dokumentu ve Wordu) }\end{array}$ \\
\hline 1.21 .7 & $\begin{array}{l}\text { Stupeň dokončenosti } \\
\text { Př́ibuzným tématem je míra, do jaké je system navržen } \\
\text { generovat integrovaný text - ve formě zprávy zcela } \\
\text { připravené k použití - nebo sadu „poznámek“, } \\
\text { komentářuu, hypotéz atd. Druhá možnost je mnohem } \\
\text { užitečnější, když je text uživateli k dispozici v } \\
\text { modifikovatelné formě a může tvořit základ pro vlastní } \\
\text { zprávu uživatele. V mnoha př́padech jsou zprávy } \\
\text { navrženy jako prezentace s velmi vysokým standardem, } \\
\text { s „publikačním“ vzhledem a kvalitou. }\end{array}$ & $\begin{array}{l}\square \\
\square\end{array}$ & $\begin{array}{l}\text { Publikační kvalita } \\
\text { Kvalita pracovní verze }\end{array}$ \\
\hline 1.21 .8 & $\begin{array}{l}\text { Transparence } \\
\text { Systémy se liší svojí otevřeností nebo transparentností } \\
\text { vǔči uživateli. Otevřený system je ten, kde je spojení } \\
\text { mezi skórem škály a textem jasné a jednoznačné. Taková } \\
\text { otevřenost je možná pouze tehdy, když jsou } \\
\text { prezentovány jak texty, tak skóry, a spojení mezi nimi } \\
\text { explicitně uvedeno. Jiné systémy pracují jako "černé } \\
\text { skříňky" a znesnadňují uživateli dát do vztahu skóry škál } \\
\text { a text. }\end{array}$ & $\square$ & $\begin{array}{l}\text { Jasné spojení mezi skóry konstruktů } \\
\text { a textem } \\
\text { Zatajené spojení mezi konstrukty, skóry } \\
\text { a textem } \\
\text { Směs jasných/zatajených spojení mezi } \\
\text { konstrukty, skóry a textem }\end{array}$ \\
\hline 1.21 .9 & $\begin{array}{l}\text { Styl a tón } \\
\text { Systémy se take liší v míře, do jaké nabízejí čtenáři } \\
\text { zprávy vedení nebo směr. Některé jsou deklarativní „Pan } \\
\text { X je velmi plachý a nebude dobrým prodejcem.... Jiné } \\
\text { jsou navrženy tak, aby nabízely hypotézy nebo vznášely } \\
\text { otázky: „Na základě jeho skórů na škále Y se pan X zdá } \\
\text { být velmi plachým. Pokud je to tak, mohlo by pro něho } \\
\text { být obtížné pracovat v prostředí prodeje. Je nutné to } \\
\text { v jeho př́ipadě dale prozkoumat.” }\end{array}$ & $\begin{array}{l}\square \\
\square\end{array}$ & $\begin{array}{l}\text { Direktivní } \\
\text { Hypotetizující } \\
\text { Jiné: Zpráva obsahuje jak hypotetizující } \\
\text { formulace obsahující slova jako „obvykle“ } \\
\text { nebo „mohou být považováni“, tak i } \\
\text { výhradně direktivní formulace. Odstavec } \\
\text { většinou začíná v hypotetizujícím tónu a } \\
\text { postupně přechází do tónu direktivního. }\end{array}$ \\
\hline 1.21 .10 & Zamýšlení příjemci & $\square$ & $\begin{array}{l}\text { Kvalifikovaní uživatelé testu } \\
\text { Osoby kompetentní vytvořit vlastní zprávy. } \\
\text { Kvalifikovaní uživatelé systému } \\
\text { Osoby, které nejsou kompetentní vytvořit samostatně } \\
\text { vlastní zprávy, ale mají trénink potřebný pro používání } \\
\text { zpráv generovaných systémem. } \\
\text { Respondenti testu } \\
\text { Respondent testu zpravidla nemá žádnou předchozí } \\
\text { znalost nástroje ani typu zprávy. } \\
\text { Třetí strany } \\
\text { Např. potenciální zaměstnavatel, rodič vedoucí či } \\
\text { supervizor apod. }\end{array}$ \\
\hline 1.22 & $\begin{array}{l}\text { Nabízejí distributoři službu opravy } \\
\text { a/nebo vývoje počítačových zpráv? }\end{array}$ & $\begin{array}{l}\square \\
\square\end{array}$ & $\begin{array}{l}\text { Ano } \\
\mathrm{Ne}\end{array}$ \\
\hline
\end{tabular}




\section{Část 5:}

\section{Nabídka, podmínky a náklady}

Tato část definuje, co vydavatel poskytne, komu, za jakých podmínek a za jaké ceny. Definuje podmínky kladené dodavatelem a týkající se toho, kdo smí a kdo nesmí získat materiál nástroje. Pokud jedna z možností neodpovídá podmínkám nabídky, doplňte popis relevantních podmínek.

\begin{tabular}{|c|c|c|}
\hline 1.23 & $\begin{array}{l}\text { Dokumentace poskytovaná } \\
\text { distributorem jako součást } \\
\text { testového balíku }\end{array}$ & 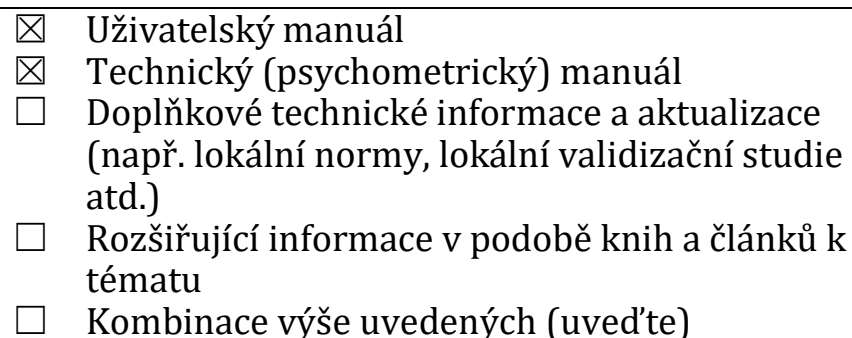 \\
\hline 1.24 & Metody publikace & $\begin{array}{ll}\bigotimes & \text { Papír } \\
\square & \text { PC - Diskety } \\
\bigotimes & \text { PC - CD/ROM } \\
\square & \text { Download z internetu } \\
\square & \text { Živý internet (nástroj pracuje v internetovém } \\
& \text { prohlížeči) } \\
\square & \text { Jiné: }\end{array}$ \\
\hline 1.25 .1 & $\begin{array}{l}\text { Počáteční náklady. } \\
\text { Cena kompletní sady materiálů (všechny manuály a } \\
\text { další material nutný k aspoñ jedné zkušební } \\
\text { administraci). Kolik uchazeču lze vyšetřovat pomocí } \\
\text { materiálú získaných za počáteční náklady, kde tyto } \\
\text { náklady zahrnují materially pro opakované vyšstř̌ení. }\end{array}$ & $\begin{array}{l}\text { Cena za možnost využívat metodu } 12000 \text { Kč, kdy } \\
\text { administrátor má k dispozici } 10 \text { dotazníků, } 30 \\
\text { záznamových archů, PC program a } 500 \text { opakování } \\
\text { vyhodnocení testu, manuál metody. }\end{array}$ \\
\hline 1.25 .2 & Opakující se náklady: & $\begin{array}{l}\text { Na každých dalších } 500 \text { vyhodnocení metody } \\
\text { v programu: } 6000 \text {,- Kč. } \\
\text { Za dalších } 10 \text { dotazníků se platí } 800 \text {,- Kč. } \\
30 \text { záznamových listů lze pořídit za 200,- Kč. }\end{array}$ \\
\hline 1.26 .1 & $\begin{array}{l}\text { Ceny za zprávy generované } \\
\text { softwarem nainstalovaným } \\
\text { uživatelem: }\end{array}$ & - \\
\hline 1.26 .2 & $\begin{array}{l}\text { Ceny za vyhotovení zprávy zaslené } \\
\text { prostřednictvím pošty/faxu: }\end{array}$ & - \\
\hline 1.26 .3 & $\begin{array}{l}\text { Ceny za vyhotovení zprávy zaslené } \\
\text { prostřednictvím internetové služby: }\end{array}$ & - \\
\hline 1.27 & $\begin{array}{l}\text { Ceny za další služby a zpracování } \\
\text { dat: opravy nebo vývoj } \\
\text { automatických zpráv: }\end{array}$ & - \\
\hline
\end{tabular}




\begin{tabular}{|c|c|c|c|}
\hline 1.28 & $\begin{array}{l}\text { Kvalifikační požadavky na práci s } \\
\text { testem vyžadované dodavatelem } \\
\text { testu }\end{array}$ & $\begin{array}{l}\square \\
\square \\
\square \\
\square \\
\square \\
\square \\
\bigotimes\end{array}$ & $\begin{array}{l}\text { Žádné } \\
\text { Oprávnění (certifikát) pro specifický test } \\
\text { Oprávnění (certifikát) pro obecné výkonové } \\
\text { testy: i. e. míry maximálního výkonu ve } \\
\text { schopnostech } \\
\text { Potvrzení v testování obecných schopností a } \\
\text { dovedností: míry maximálního výkonu ve } \\
\text { vztahu k potenciálu k výkonu } \\
\text { Potvrzení v obecné diagnostice a diagnostice } \\
\text { osobnosti: míry typického chování, postojů a } \\
\text { preferencí } \\
\text { Jiné: } \\
\text { U administrace není vyžadována žádná } \\
\text { kvalifikace kromě znalosti metody a } \\
\text { způsobu její administrace }\end{array}$ \\
\hline 1.29 & 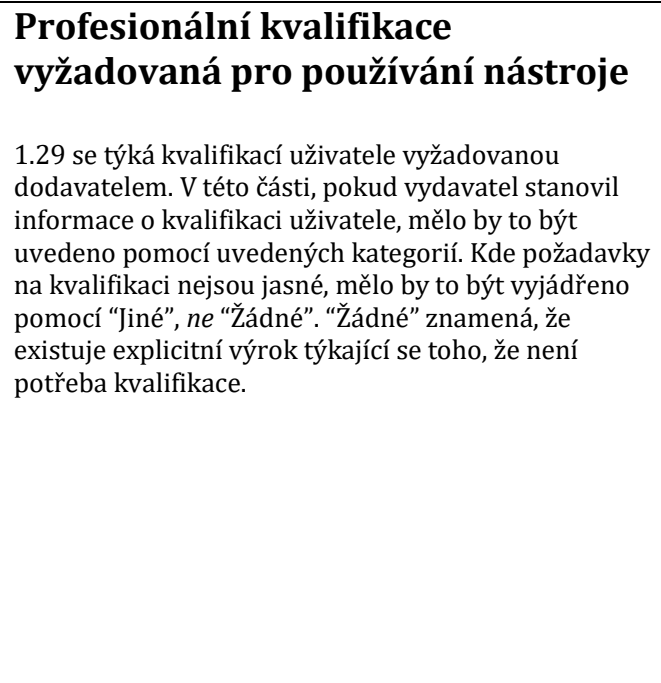 & $\begin{array}{l}\square \\
\square \\
\square \\
\bigotimes \\
\square \\
\square \\
\square \\
\square \\
\square \\
\square\end{array}$ & $\begin{array}{l}\text { Žádné } \\
\text { Praktický psycholog s kvalifikací v relevantní } \\
\text { aplikační oblasti } \\
\text { Praktický psycholog } \\
\text { Výzkumný psycholog } \\
\text { Nepsychologický akademický výzkumník } \\
\text { Praktik v relevantních příbuzných profesích } \\
\text { (terapie, medicína, poradenství, vzdělání, } \\
\text { lidské zdroje atd.) } \\
\text { Držitel Certifikátu způsobilosti pro testování } \\
\text { v psychologii práce A BPS } \\
\text { Držitel Certifikátu způsobilosti pro testování } \\
\text { v oblastni vzdělávacím A BPS } \\
\text { Držitel Certifikátu způsobilosti pro testování } \\
\text { v psychologii práce B BPS } \\
\text { Jiné: }\end{array}$ \\
\hline
\end{tabular}

Č́ást 6:

Hodnocení testových materiálů

\section{Vysvětlení hodnocení}

V následujících částech jsou celková posouzení adekvátnosti informací týkajících se validity, reliability a norem zobrazeny automaticky tučně.

Jakýkoli nástroj s jedním nebo více posouzeními 0 nebo 2 týkajícími se atributů považovaných za kritické pro bezpečné používání nástroje, by neměl být považován za nástroj, který splňuje minimální standardy. 


\begin{tabular}{|c|c|c|c|}
\hline $\begin{array}{l}\text { Vstup na posuzovacím } \\
\text { formuláři }\end{array}$ & $\begin{array}{l}\text { Posouzení podle } \\
\text { standardi̊ EFPA }\end{array}$ & $\begin{array}{c}\text { Reprezentace recenze } v \\
\mathrm{UK}\end{array}$ & Vysvětlení \\
\hline [n/a] & [n/a ] & [n/a ] & $\begin{array}{l}\text { Tento atribut není u tohoto } \\
\text { nástroje použitelný }\end{array}$ \\
\hline $\mathbf{0}$ & {$[-]$} & [None ] & $\begin{array}{l}\text { Není možné posoudit jako } \\
\text { ne nebo nedostatek } \\
\text { poskytnutých informací }\end{array}$ \\
\hline 1 & {$[-1]$} & {$\left[\begin{array}{ll}* & ]\end{array}\right.$} & Neadekvátní \\
\hline 2 & & {$\left[\begin{array}{ll}* * & ]\end{array}\right.$} & NYNÍ NEPOUŽÍVÁNO \\
\hline 3 & {$\left[\begin{array}{ll}0 & 0\end{array}\right]$} & {$[* * *]$} & Adekvátní nebo přiměřený \\
\hline 4 & [ 1 ] & {$[* * * *]$} & Dobrý \\
\hline \multirow[t]{2}{*}{5} & [ 2 ] & {$[* * * * *]$} & Vynikající \\
\hline & & $\begin{array}{l}\text { [N.r.i.o.r] }{ }^{*} \text { (pouze pro } \\
\text { aktualizace) }\end{array}$ & $\begin{array}{l}\text { Položka nebyla v původní } \\
\text { recenzi posuzována }\end{array}$ \\
\hline
\end{tabular}

V této části má být provedeno více hodnocení různých aspektů nebo atributů dokumentace dodávané s nástrojem (nebo balíkem). Termín „dokumentace“ byl vybrán, aby pokrýval všechny ty materiály dodávané s nástrojem nebo snadno dostupné kvalifikovanému uživateli: např. manual administrátora; technické př́ručky; brožury s normami; dodatky k manuálu; aktualizace od vydavatelů/dodavatelů atd.

Položky mají být posuzovány n/a nebo 0 až 5 (poloviční rating je přijatelný)

\section{Rating}

\begin{tabular}{|c|c|c|}
\hline \multicolumn{2}{|r|}{$\begin{array}{l}\text { Kvalita vysvětlení principů, prezentace a kvalita poskytnuté informace: } \\
\text { (Tento celkový rating se získá použitím posouzení založeného na ratinzích daných pro položky } 2.1-2.8 \text { ) }\end{array}$} & $3 ; 3$ \\
\hline 2.1 & $\begin{array}{l}\text { Celkový rating kvality vysvětlení principů: (Tento celkový rating se získá použitím } \\
\text { posouzení založeného na hodnotách ratingů daných pro položky } 2.1 .1-2.1 .5)\end{array}$ & $1 ; 1$ \\
\hline 2.1 .1 & i) Teoretické základy konstruktů: & $1 ; 0$ \\
\hline 2.1 .2 & ii) Procedura vývoje testu: & $2 ; 1$ \\
\hline 2.1 .3 & iii) Důkladnost analýz položek a model analýzy položek: & $3 ; 3$ \\
\hline 2.1 .4 & iv) Vysvětlení obsahové validity: & $2 ; 1$ \\
\hline 2.1 .5 & v) Souhrn relevantního výzkumu: & $3 ; 3$ \\
\hline 2.2 & $\begin{array}{l}\text { Adekvátnost dokumentace dostupné uživateli (uživatelské a technické } \\
\text { manuály, dodatky týkající se norem atd.): (Tento celkový rating se získá použitím } \\
\text { posouzení založeného na hodnotách ratingů daných pro položky } 2.2 .1-2.2 .6 \text { ) } \\
\text { Pro část } 2.2 \text { jsou stanoveny následující „měřítka“ pro rating „vynikajíci““ (5). Pozornost je zde zaměřena } \\
\text { na kvalitu pokrytí poskytnutého v dokumentaci dostupné kvalifikovaným uživatelüm. Všimněte si, že část } 2.2 \\
\text { se týká úplnosti a jasnosti dokumentace dostupné uživateli (uživatelské a technické manually, doadtky } \\
\text { k normám atd.) v pojmech pokrytí a vysvětlení. V pojmech kvality nástroje, jak ji dosvědčuje dokumentace, } \\
\text { jsou rozpracovány oblasti v této části pod čísly: } 2.1,2.3,2.9,2.10 \text { a } 2.11 \text {. }\end{array}$ & $3 ; 3$ \\
\hline 2.2 .1 & $\begin{array}{l}\text { Principy: [viz 2.1] } \\
\text { Dobře argumentovaný a jasně prezentovaný popis toho, co má podle návrhu měřit a proč byl zkonstruován } \\
\text { tak, jak je. }\end{array}$ & $4 ; 4$ \\
\hline 2.2 .2 & $\begin{array}{l}\text { Vývoj: } \\
\text { Úplné detaily týkající se zdrojů položek, pilotáže, analýz položek, srovnávacích studií a změn prováděných v } \\
\text { průběhu vývojových pokusŭ. }\end{array}$ & $3 ; 3$ \\
\hline 2.2 .3 & $\begin{array}{l}\text { Standardizace: } \\
\text { Jasné a detailní informace poskytnuté o velikostech a zdrojích standardizačního souboru a standardizační } \\
\text { proceduře. }\end{array}$ & $2 ; 1$ \\
\hline 2.2 .4 & $\begin{array}{l}\text { Normy: } \\
\text { Jasné a detailní informace poskytnuté o velikostech a zdrojích normalizačních skupin, podmínkách vyšetření } \\
\text { atd. }\end{array}$ & $4 ; 4$ \\
\hline 2.2 .5 & $\begin{array}{l}\text { Reliabilita: } \\
\text { Dobré vysvětlení reliability a široký rozsah měr vnitřní konsistence a retestu spolu s vysvětlením jejich } \\
\text { relevance a zobecnitelnosti nástroje vyšetření. }\end{array}$ & $2 ; 1$ \\
\hline
\end{tabular}




\section{Informace o normách nebo referenční skupině}

\begin{tabular}{|c|c|c|}
\hline 2.9 & Celková adekvátnost: & 3 \\
\hline 2.9 .1 & 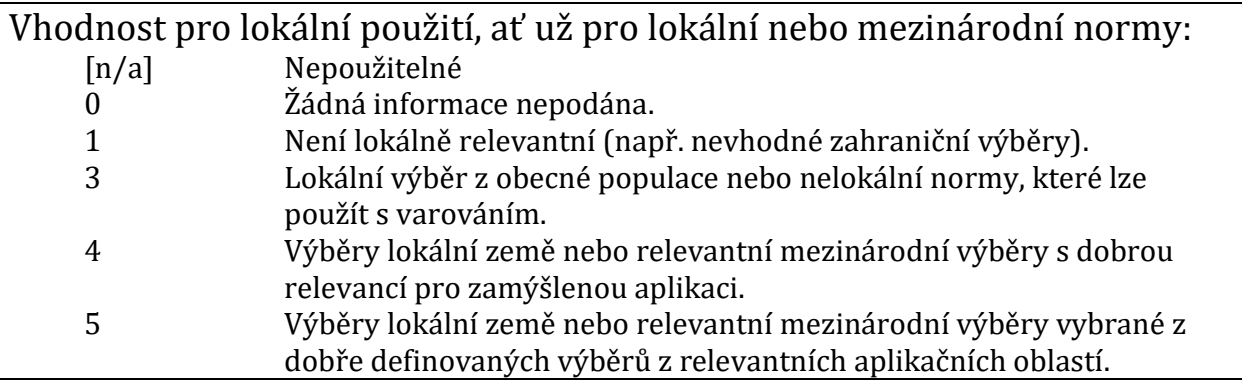 & 4 \\
\hline 2.9 .2 & $\begin{array}{ll}\begin{array}{l}\text { Vhodnost pro zamýšlené aplikace: } \\
{[\mathrm{n} / \mathrm{a}]}\end{array} & \begin{array}{l}\text { Nepoužitelné } \\
0\end{array} \\
1 & \text { Žádná informace nepodána. } \\
3 & \text { Norma nebo normy nejsou adekvátní pro zamýšlené aplikace. } \\
& \begin{array}{l}\text { Adekvátní normy pro obecnou populaci a/nebo rozmezí normativních } \\
\text { tabulek. }\end{array} \\
5 & \begin{array}{l}\text { Dobré rozmezí normativních tabulek. } \\
\text { Vynikající rozmezí výběrově relevantních norem vztahujících se k věku } \\
\text { a pohlaví, s informacemi o dalších rozdílech v rámci skupin (např. } \\
\text { směs etnických skupin). }\end{array} \\
\end{array}$ & 3 \\
\hline 2.9 .3 & \begin{tabular}{ll}
\multicolumn{2}{l}{$\begin{array}{l}\text { Velikosti výběrů: } \\
{[\mathrm{n} / \mathrm{a}]}\end{array}$} \\
0 & Nepoužitelné \\
1 & Žádná informace nepodána. \\
3 & Neadekvátní výběry (např. méně než 150). \\
4 & Adekvátní výběry (např. 150-300). \\
5 & Velké výběry (např. 300-1000). \\
\end{tabular} & 4 \\
\hline 2.9 .4 & $\begin{array}{cl}\text { Procedury použité při výběru souboru: } \\
\square & \text { Žádná informace neposkytnuta } \\
\bigotimes & \text { Reprezentativní populaci [sumarizujte kritéria] } \\
\square & \text { Nahodilá } \\
\square & \text { Náhodná } \\
\end{array}$ & \\
\hline 2.9 .5 & 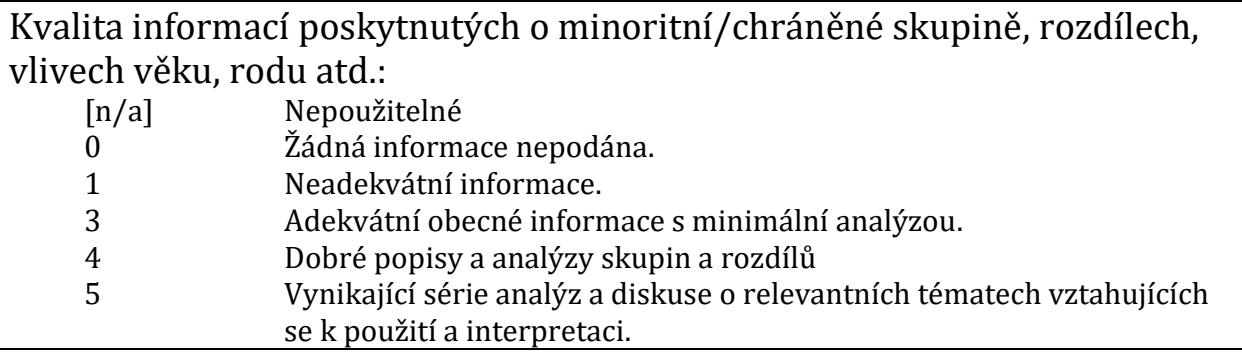 & 0 \\
\hline
\end{tabular}

2.9.6 Komentáře recenzentů k normám: Stručná zpráva o normách a jejich historii, včetně informací o doporučeních učiněných vydavatelem/autorem pro aktualizaci norem obvyklým způsobem.

Je-li hodnocení provedeno zárově pro českou i původní verzi testu, jsou hodnocení uvedena ve formě Originální verze; Česká verze. $V$ př́ípadě jednoho hodnocení bylo hodnocení provedeno pouze pro českou verzi testu.

Položky inventáře byly nezávisle přeloženy 2 jazykovými odborníky a 1 psychologem. Poté byla prvotní verze dotazníku konzultována 4 psychology a 1 odborníkem. Druhou verzi připomínkoval vydavatel. Počáteční soubor u standardizační studie byl zredukován o 215 osob (z původních 865) ze dvou důvodů. Prvním bylo nevyvážené rozložení skupin ve vztahu ke kritériím vzdělání a věk a druhým důvodem bylo překročení maximálního počtu nezodpovězených otázek (30) a vyššího hrubého skóru u škál $F$ a $F_{B}$, nemá být vyšší než 20.

České normy byly vytvořeny na vzorku 650 osob z toho bylo 325 mužů a 325 žen. Respondentů s dokončenou základní školou bylo 84, střední školou 211 a s vysokou školou 355 . Věk respondentů 


\section{Validita}

\begin{tabular}{|c|c|c|}
\hline 2.10 & $\begin{array}{l}\text { Celková adekvátnost: (Tento celkový rating se získá na základě posouzení hodnot ratingů } \\
\text { daných v položkách } 2.10 .1 \text { - } 2.10 .2 .4 \text {. Neprůměrujte pouze čísla, abyste získali celkový rating. } \\
\text { Obvykle bude roven bud' konstruktové validitě nebo validitě vztahující se ke kritériu, podle } \\
\text { toho, která z nich je vyššsi.) }\end{array}$ & $1 ; 1$ \\
\hline 2.10 .1 & $\begin{array}{l}\text { Konstruktová validita - celková adekvátnost } \\
\text { (Tento celkový rating se získá na základě posouzení hodnot ratingů daných v položkách } \\
\text { 2.10.1.2 - 2.10.1.6. Neprủměrujte pouze čísla, abyste tento celkový rating získali.) }\end{array}$ & $1 ; 1$ \\
\hline 2.10 .1 .1 & \multicolumn{2}{|l|}{\begin{tabular}{|c|c|} 
Použité plány: (zatrhněte tolik, kolik je jich použitelných) \\
$\square$ & Žádná informace nepodána \\
$\square$ & Korelace s dalšími nástroji a výkonovými kritérii \\
$\square$ & Vnitroškálový (korelace položky se zbytkem) \\
$\bigotimes$ & Rozdíly mezi skupinami \\
$\bigotimes$ & Matice mnoha rysů a mnoha metod (MTMM) \\
$\square$ & Explorační faktorová analýza \\
$\bigotimes$ & Konfirmační faktorová analýza \\
$\square$ & Experimentální plány \\
$\square$ & iné: uved'te \\
\end{tabular}} \\
\hline 2.10 .1 .2 & $\begin{array}{cl}\text { Velikosti výběrů: } & \\
0 & \text { Žádná informace neposkytnuta. } \\
1 & \text { Jedna neadekvátní studie (např. velikost výběru menší než 100). } \\
3 & \text { Jedna adekvátní studie (napřr. velikost výběru 100-200). } \\
4 & \text { Více než jedna adekvátní nebo velká studie. } \\
5 & \text { Dobrá série adekvátních až rozsáhlých studií. }\end{array}$ & $1 ; 1$ \\
\hline 2.10 .1 .3 & \multicolumn{2}{|l|}{$\begin{array}{cl}\text { Procedura výběru souboru: (vyberte jednu) } \\
\square \quad \text { Žadná informace neposkytnuta } \\
\bigotimes \quad \text { Reprezentativní vǔči populaci [sumarizujte kritéria] } \\
\square \quad \text { Nahodilá } \\
\square \quad \text { Náhodná }\end{array}$} \\
\hline 2.10 .1 .4 & $\begin{array}{cl}\text { Medián a rozsah korelací mezi testem a dalšími podobnými testy: } \\
0 & \text { Žádná informace neposkytnuta. } \\
1 & \text { Neadekvátní }(\mathrm{r}<0.55) . \\
3 & \text { Adekvátní }(0.55<\mathrm{r}<0.65) \\
4 & \text { Dobrý }(0.65<\mathrm{r}<0.75) . \\
5 & \text { Vynikající }(\mathrm{r}>0.75) \\
\end{array}$ & $0 ; 0$ \\
\hline 2.10 .1 .5 & $\begin{array}{cl}\text { Kvalita nástrojů jako kritérií nebo markerů: } \\
0 & \text { Žádná informace neposkytnuta. } \\
1 & \text { Poskytnuta neadekvátní informace. } \\
3 & \text { Adekvátní kvalita. } \\
4 & \text { Dobrá kvalita. } \\
5 & \text { Vynikajíć kvalita s širokým rozsahem relevantních markerů pro } \\
& \text { konvergentní a divergentní validizaci. } \\
\end{array}$ & $0 ; 0$ \\
\hline 2.10 .1 .6 & $\begin{array}{cl}\text { Analýzy diferenciálního fungování položek (DIF): } \\
\text { [N/A ] } & \text { Nepoužitelné } \\
0-5 & \text { hodnocení kvality DIF analýzy } \\
\end{array}$ & $0 ; 0$ \\
\hline 2.10 .2 & $\begin{array}{l}\text { Validita vztahující se ke kritériu - celková adekvátnost } \\
\text { (Tento celkový rating se získá na základě posouzení hodnot atatingů daných v položkách } \\
\text { 2.11.1 - 2.10.2.4. Neprủměrujte pouze čísla, abyste získali celkový rating.) }\end{array}$ & $1 ; 1$ \\
\hline 2.10 .2 .1 & 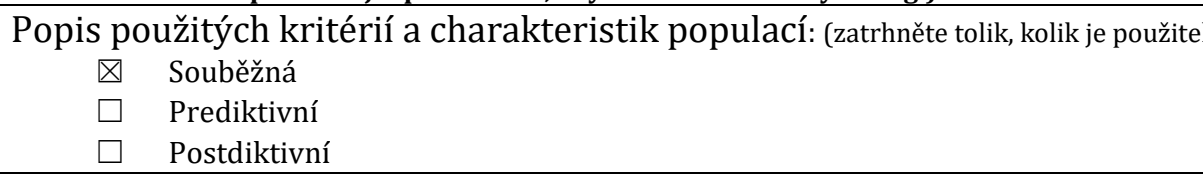 & \\
\hline
\end{tabular}




\begin{tabular}{|c|c|c|c|}
\hline 2.10 .2 .2 & $\begin{array}{c}\text { Velikc } \\
0 \\
1 \\
3 \\
4 \\
5 \\
\end{array}$ & $\begin{array}{l}\text { ýběrů: } \\
\text { Žádná informace neposkytnuta. } \\
\text { Jedna neadekvátní studie (např̀. velikost výběru menší než 100). } \\
\text { Jedna adekvátní studie (např̀ velikost výběru 100-200). } \\
\text { Jedna velká nebo vice než jedna adekvátně rozsáhlá studie. } \\
\text { Dobrá série adekvátních až rozsáhlých studií. }\end{array}$ & $1 ; 1$ \\
\hline 2.10 .2 .3 & \multicolumn{2}{|c|}{$\begin{array}{ll}\square & \text { Žádná informace neposkytnuta } \\
\bigotimes & \text { Účelná nebo reprezentativní } \\
\square & \text { Nahodilá } \\
\square & \text { Náhodná }\end{array}$} & \\
\hline 2.10 .2 .4 & \begin{tabular}{|c|} 
Mediár \\
0 \\
1 \\
3 \\
4 \\
5 \\
\end{tabular} & $\begin{array}{l}\text { a rozsah korelací mezi testem a kritérii: } \\
\text { Žádná informace neposkytnuta. } \\
\text { Neadekvátní (např. } r<0.2 \text { ). } \\
\text { Adekvátní (napřr. } 0.2<\mathrm{r}<0.35 \text { ). } \\
\text { Dobrý (např. } 0.35<\mathrm{r}<0.50 \text { ). } \\
\text { Vynikající (např. } \mathrm{r}>0.50 \text { ) }\end{array}$ & $0 ; 0$ \\
\hline \multicolumn{4}{|c|}{ 2.10.3 Komentáře recenzenta týkající se validity: } \\
\hline \multicolumn{4}{|c|}{$\begin{array}{l}\text { Je-li hodnocení provedeno zárově pro českou i původní verzi testu, jsou hodnocení uvedena ve formě } \\
\text { Originální verze; Česká verze. V př́padě jednoho hodnocení bylo hodnocení provedeno pouze pro } \\
\text { českou verzi testu. }\end{array}$} \\
\hline \multicolumn{4}{|c|}{ 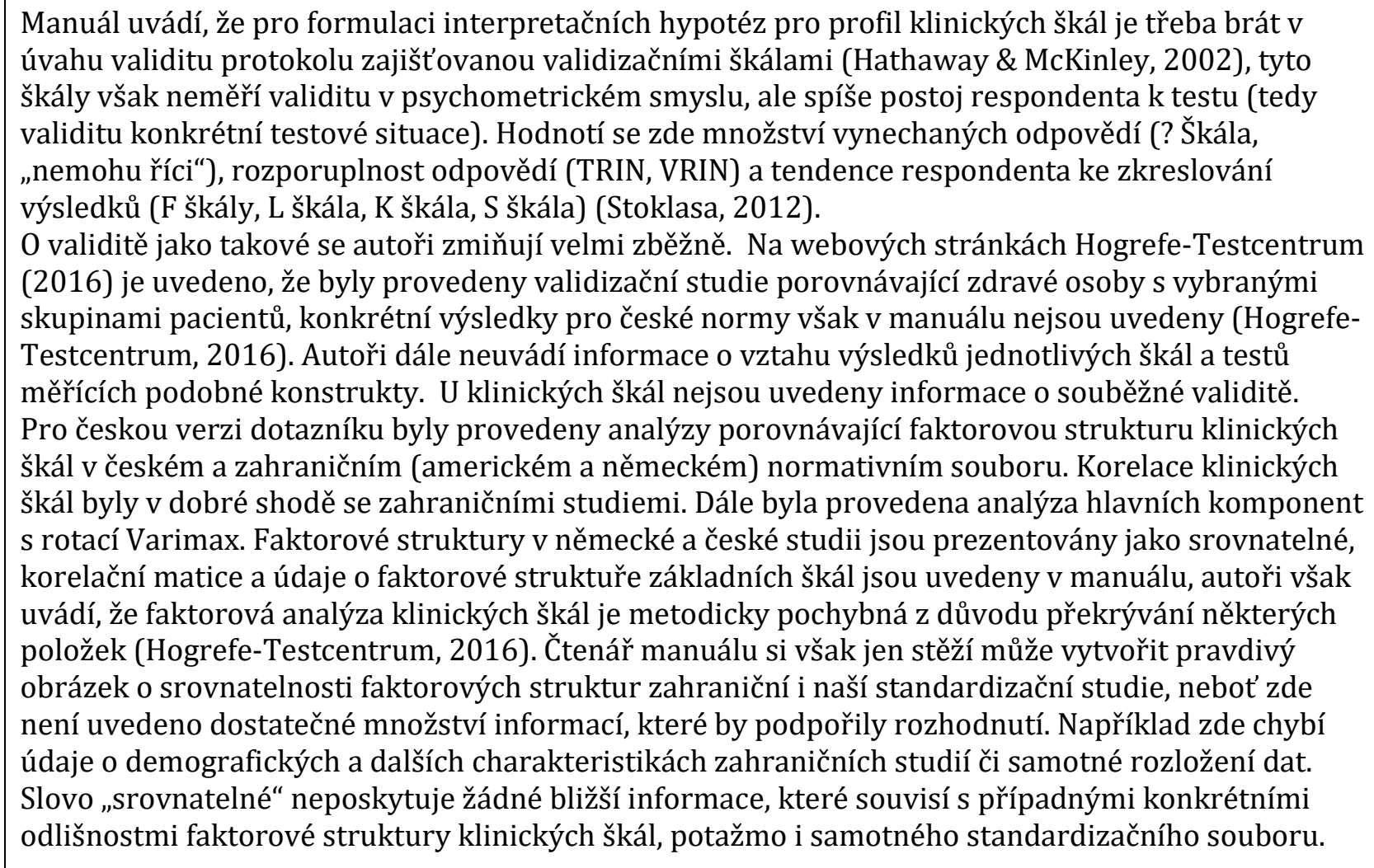 } \\
\hline
\end{tabular}

\section{Reliabilita}

\begin{tabular}{|l|l|c|}
\hline 2.11 & $\begin{array}{l}\text { Celková adekvátnost: } \\
\text { (Tento celkový rating se získá na základě posouzení hodnot ratingů daných v položkách 2.11.1-2.10.2.4. } \\
\text { Neprůměrujte pouze čísla, abyste získali celkový rating.) }\end{array}$ & $\mathbf{1 , 5 ; 1}$ \\
\hline
\end{tabular}




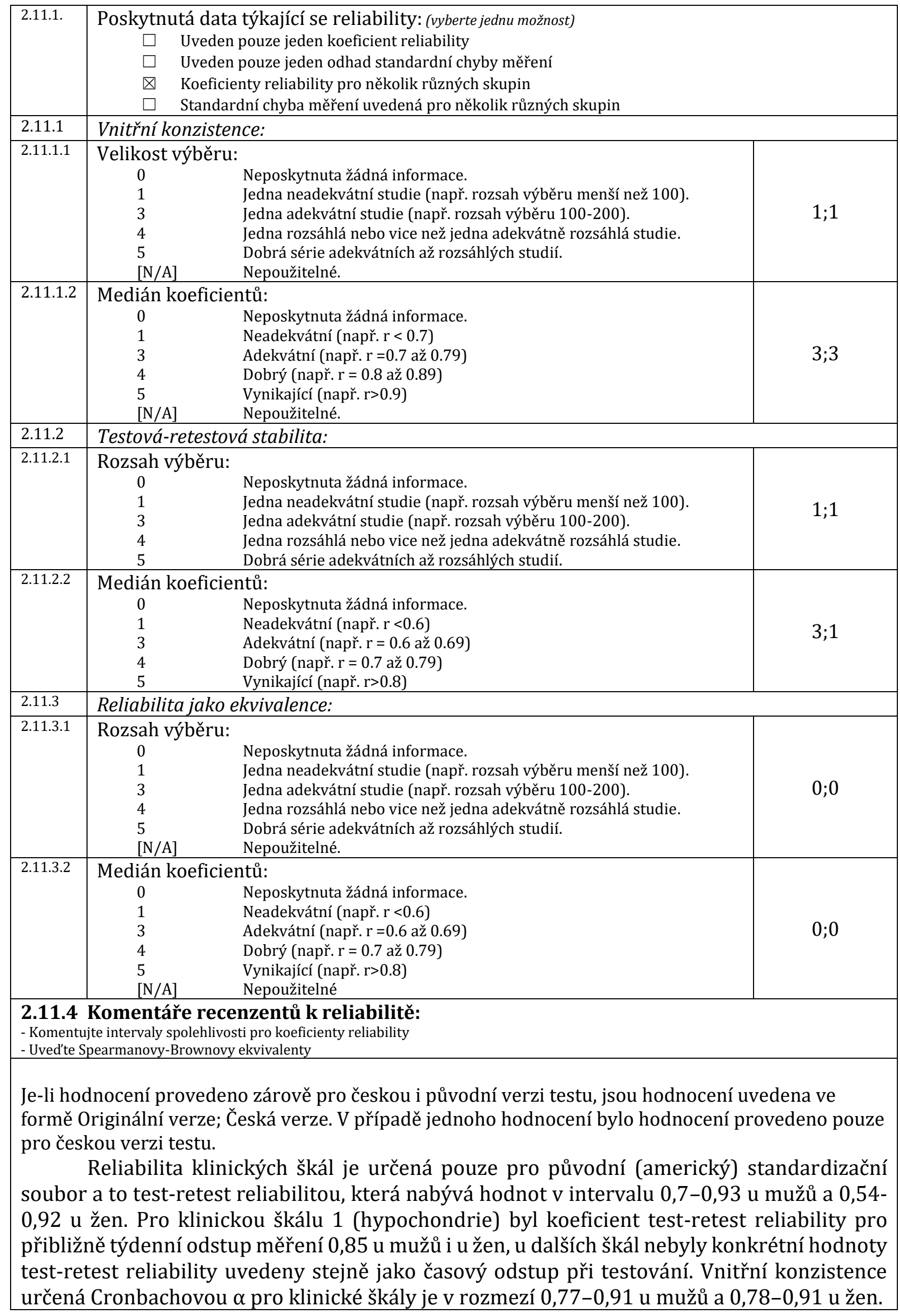


Reliability škál byly počítány během restandardizačních studií a konkrétní hodnoty pro jednotlivé škály jsou uvedeny pouze v manuálu Butcher et al. (2001), na který se manuál odkazuje (Netík, 2002). Během české standardizační studie nebyly hodnoty reliability pro jednotlivé škály přepočítány. $\mathrm{V}$ manuálu dále nejsou uvedeny intervaly spolehlivosti pro jednotlivé škály.

\section{Část 8: \\ Kvalita počítačově generovaných zpráv:}

Položky mají být posuzovány n/a nebo 0 až 5 (poloviční rating je přijatelný)

Rating

\begin{tabular}{|c|c|c|}
\hline 2.12 & $\begin{array}{l}\text { Celková adekvátnost počítačově generovaných zpráv: } \\
\text { (Tento celkový rating se získá na základě posouzení hodnot ratingů daných pro položky 2.12.1-2.12.7. } \\
\text { Neprůměrujte pouze hodnoty, abyste získali celkový rating.) }\end{array}$ & 3 \\
\hline 2.12 .1 & 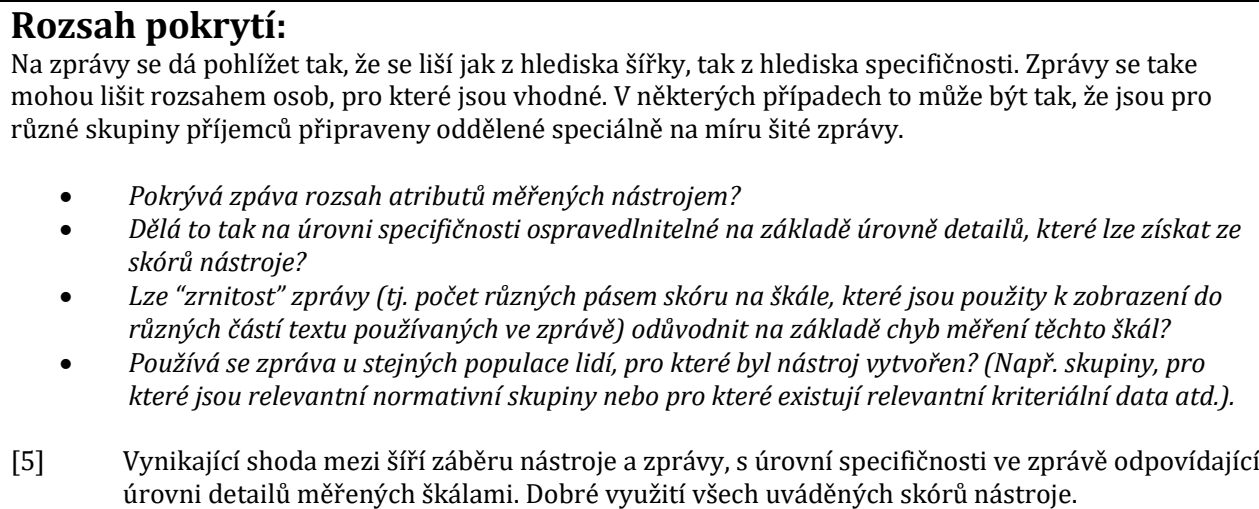 & 3 \\
\hline 2.12 .2 & $\begin{array}{l}\text { Reliabilita } \\
\text { - Jak konsistentní jsou zprávy ve své interpretaci podobných sad skórů? } \\
\text { - Pokud je obsah zprávy variabilní (např. náhodným výběrem z ekvivalentních částí textu), je to } \\
\text { prováděno uspokojivě? } \\
\text { - Je interpretace skórü a rozdílů mezi skóry ospravedlnitelná z hlediska chyb měření škál? } \\
\text { [5] } \quad \begin{array}{l}\text { Vynikající konsistence při interpretaci a prriměřená varování poskytnutá u tvrzení, interpretací } \\
\text { a doporučení týkajících se souvisejících chyb měření. }\end{array}\end{array}$ & 3 \\
\hline 2.12 .3 & $\begin{array}{l}\text { Relevance neboli validita } \\
\text { Spojení mezi nástrojem a obsahem zprávy může být bud' vysvětlena v rámci zprávy nebo dokumentováno } \\
\text { odděleně. Kde jsou zprávy založené na klinickém úsudku, by měl být dokumentován proces, kterým } \\
\text { expert(i) vytvářel(i) obsah a pravidla dávající do vztahu skóry a obsah. } \\
\text { - Jak silný je vztah mezi obsahem zprávy a skóry nástroje? Do jaké míry jde zpráva za nebo se } \\
\quad \text { rozchází s informacemi poskytovanými skóry nástroje? } \\
\text { - Je obsah zprávy v jasném vztahu k charakteristikám měřeným nástrojem? } \\
\text { Poskytuje rozumné závěry o kritériích, ke kterým můžeme očekávat, že budou takové } \\
\text { charakteristiky ve vztahu? } \\
\text { - Jaké empirické důkazy jsou poskytnuty, které ukazují, že tyto vztahy skutečně existují? } \\
\text { Je relevantní uvažovat jak o konstruktové validitě zprávy (tj. míře, do jaké poskytuje interpretaci, která je } \\
\text { ve shodě s přislušnými konstrukty) a kriteriální validitě (tj. kde jsou formulovány výroky, které lze davit } \\
\text { zpětně do vztahu s empirickými daty). } \\
\text { [5] }\end{array}$ & 1 \\
\hline
\end{tabular}




\begin{tabular}{|c|c|c|}
\hline 2.12 .4 & $\begin{array}{l}\text { Spravedlnost neboli nezávislost na systematickém zkreslení } \\
\text { • Mohl by obsah zprávy a použitý jazyk vytváret dojem nepatřičnosti pro určité skupiny? } \\
\text { - Vyjasñuje zpráva jakékoli oblasti možného zkreslení ve výsledcích nástroje? } \\
\quad \begin{array}{l}\text { Jsou k dispozici formy v alternativních jazycích? Pokud ano, byly podniknuty adekvátní kroky } k \\
\text { zajišténí jejich ekvivalence? }\end{array} \\
\text { [5] Vynikající, jasná varování a vysvětlení možného zkreslení, dostupné ve všech relevantních } \\
\text { uživatelských jazycích }\end{array}$ & 1 \\
\hline 2.12 .5 & $\begin{array}{l}\text { Přijatelnost } \\
\text { Ta bude velmi záviset na komplexnosti jazyka použitého ve zprávě, složitosti popisovaných konstruktů a } \\
\text { účelu, pro jaký je určena. } \\
\text { • Dá se očekávat, že forma a obsah zprávy budou přijatelné zamýšleným př́ijemcúm? } \\
\text { - Je zpráva napsána jazykem, který je přiměřený pravděpodobným úrovním počtárské zběhlosti a } \\
\text { gramotnosti předpokládaného čtenáre? } \\
\text { [5] Velmi vysoká přijatelnost, dobře navržená a dobře se hodící předpokládaným př́ijemcům }\end{array}$ & 4 \\
\hline 2.12 .6 & $\begin{array}{l}\text { Praktičnost } \\
\text { Otázky praktičnosti take ovlivňují přijatelnost. Hlavní praktická výhoda počítačově generovaných zpráv je } \\
\text { ta, že šetří čas osoby, která by jinak musela zprávu vytvořit. Když tato osoba není koncový uživatel, } \\
\text { argumenty týkající se praktičnosti mohou být obtížněji formulovatelné. } \\
\text { • Kolik času šetří každá zpráva uživateli? } \\
\text { - Kolik času zabere čtení a používání každé zprávy? } \\
\text { [5] Vynikající z hlediska efektivity a hodnoty. }\end{array}$ & 1 \\
\hline 2.12 .7 & $\begin{array}{l}\text { Délka } \\
\text { Toto je aspekt praktičnosti a měl by se projevit v tomto ratingu. Konkrétněji poskytuje index } \\
\text { poměru kvantity výstupu ku vstupu. Počet škál, na kterých je založen obsah zprávy, je } \\
\text { považován za vstup, a počet stránek zprávy (mimo titulních stránek, poznámek týkajících se } \\
\text { copyrightu atd.) jsou považovány za výstup. } \\
\text { Pro výpočet tohoto indexu sečtěte počet škál včetně odvozených a kompozitních škál (např. pro } \\
\text { osobnostní míry, faktorové škály vyššího řádu, škály pro typy týmů, styly vedení atd. Mohou } \\
\text { být odvozeny ze základních škál). } \\
\qquad \begin{array}{l}1 . \quad \text { Vydělte celkový počet stránek počtem škál. } \\
2 \text {. Vynásobte tento zlomek } 10 \text { a zaokrouhlete výsledek na nejbližší celé číslo. }\end{array} \\
\text { Hodnoty vyšší než } 10 \text { obecně pravděpodobně indikují zprávy, které jsou nadměrně dlouhé a } \\
\text { přehnaně interpretující }\end{array}$ & 0 \\
\hline
\end{tabular}

\subsubsection{Komentáře recenzentů k počítačově generovaným zprávám:}

Zprávy o výsledcích respondenta je možné vygenerovat pouze počítačově. Po vložení dat do systému počítač vygeneruje výsledné skóry škál spolu s grafickým znázorněním hodnot jednotlivých kategorií klinických škál. Podle profilu klinických škál počítač určí kódový typ. Existuje 381 kombinací kódových typů. Na základě kódového typu program vytvoří text, který lze následně exportovat do Wordu.

Zobrazený text je v české verzi velmi stručný, psaný kombinací hypotetizujících a direktivních tvrzení. Text je dělen do tří odstavců, kterými jsou „Symptomy a chování, „Osobnostní charakteristiky“ a „Predikce či dispozice“. Následuje výčet 123 škál a jejich hodnot bez dalšího vysvětlení.

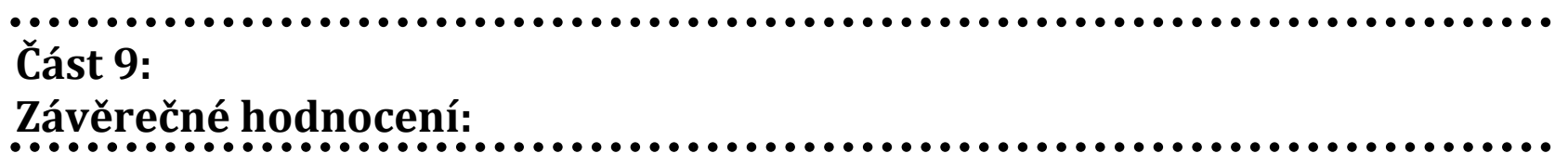

\subsection{Hodnotící zpráva testu:}

Tato část by měla obsahovat stručné, jasně obhájené posouzení nástroje/produktu. Mělo by popisovat jeho pro a proti a poskytnout určitá obecná doporučení týkající se toho, jak a kdy by se měl používat - spolu s varováními (kde jsou potřebná) týkajícími se případů, kde by se používat neměl.

MMPI-2 je metoda, která má přinést komplexní pohled na osobnost člověka. Je primárně určená pro využívání v diagnostice a klinické praxi. V současnosti se však hojně využívá i v jiných oblastech, 
např́klad $\mathrm{v}$ psychologii organizace, při výběrových řízeních atd. $\mathrm{V}$ České republice je metoda oblíbeným a hojně využívaným nástrojem i přes mnoho chybějících relevantních informací a otazníků, které se objevují při bližším zkoumáním metody. Nutno však podotknout, že minimálně v zahraničí dochází k tvorbě restandardizačních studí a dalšímu následnému vylepšování metody. Jako příklad by se dalo uvést, že $\mathrm{v}$ reakci na častou připomínku ohledně vysoké heterogenity škál a překrývání konceptů (viz v Doebbeling et al., 2005), které škály měří, došlo k restrukturaci klinických škál (viz. pozn1).

Za metodou nestojí žádná konkrétní teorie, jde pouze o názorovou shodu odborníků, kdy bylo předpokládáno, že komplexnější metoda, která bude měřit mnoho konstruktů na relativně malém počtu položek, bude užitečnější, než mnoho specifických testů. Výhodou takového testu by mělo být zejména vytváření norem pro více konstruktů na jedné populaci, což by mohlo zjednodušit interpretaci a umožnit lepší srovnávání jednotlivých skórů (Hathaway \& McKinley, 1940).

Manuál se velmi detailně věnuje interpretaci jednotlivých škál a popisuje ji smysluplně, avšak mnoho jiných důležitých informací pro posouzení vhodnosti metody v něm chybí. Například detailní popis reliability jednotlivých škál, popis validity, nebo popis tvorby jednotlivých položek.

Také tvorbu norem lze považovat za problematickou. Při tvorbě norem pro Českou republiku byl použit velmi malý standardizační vzorek, který je vzhledem k míře používání metody možné považovat za nedostatečný. Dále zde nejsou informace o férovosti položek k menšinám žijícím v ČR (tím se ale nezabýval ani Americký manuál). Další nevýhodou této metody je absence transparentnosti celého procesu vyhodnocování testu. Vyhodnocovací program je sice uživatelsky příjemný, ale chybí zde mnoho vhodných informací pro výslednou interpretaci (např. intervaly spolehlivosti pro výsledné skóry).

\subsection{Závěry:}

Součaný stav inventáře by bylo vhodné podrobit bližšímu výzkumnému šetření se zaměřením se na popis reliability škál a validity celé metody. $Z$ výše uvedených důvodů by se měla zvážit revize inventáře.

\subsection{Doporučení (vyberte jedno)}

Všechny následující charakteristiky uvedené níže by měly mít ratingy [n/a], [2], [4], [5], pokud by měl být nástroj „doporučen“ pro obecné použití (hodnocení 5 nebo 6):

[2.9] Normy a referenční skupiny [2.10.1] Konstruktová validita

[2.10.2] Kriteriální validita

[2.11] Reliabilita - celková

[2.12] Počítačově generované

zprávy

Pokud má kterýkoli z výše uvedených ratingů hodnotu [] nebo [1], nástroj by měl být klasifikován pod doporučením 1, 2, 3 nebo 4, nebo klasifikován pod doporučením 7 "jiné" s adekvátním vysvětlením.
1 Pouze výzkumný nástroj. Ne pro užití v praxi.

2 Vhodný pouze pro užití expertním uživatelem za pečlivě kontrolovaných podmínek nebo ve velmi omezených aplikačních oblastech

\ 3 Vhodný pro použití pod supervizí v aplikační(ch) oblasti(ech) definovaných distributorem, libovolnými uživateli $\mathrm{s}$ obecnými kompetencemi pro používání a administraci testů

4 Vyžaduje další vývoj. Vhodný pouze pro použití ve výzkumu.

5 Vhodný pro používání $\mathrm{v}$ aplikační(ch) oblasti(ech) definovaných distributorem, uživateli testů, kteří splňují speciální kvalifikační požadavky distributora

6 Vhodný pro sebevyšetření bez supervise $\mathrm{v}$ aplikační(ch) oblasti(ech) definovaných distributorem

7 Jiné:

5 Odkazy k poznámkám a bibliografie 
Baer, R. A., Berry, D. T. R., Greene, R., Nichols, D. S., \& Wetter, M. W. (1995). Sensitivity of MMPI-2 Validity Scales to Underreporting of Symptoms. Psychological Assessment, 7 (4), s. 419-423.

Butcher, J. N. (2001). Minnesota Multiphasic Personality Inventory (MMPI).

Cicchetti, D. V. (1994). Guidelines, Criteria, and Rulez of Thumb for Evaluating Normed and Standardized Assessment Instruments in Psychology. Psychological Assessment, 6(4), s. 284-290.

Doebbeling, B. N., Simms, L. J., Casillas, A., Clark, L. A., \& Watson, D. (2005). Psychometric Evaluation of the Restructed Clinical Scales of the MMPI-2. Psychological Assessment, 17 (3), s. 345-358.

Dahlstrom, W. G., Welsh, G. S., \& Dahlstrom, L. E. (1972). An MMPI handbook: I. Clinical interpretation.(Rev.)

Greene, R. L. (2000). The MMPI-2: An interpretive manual. Allyn \& Bacon.

Hathaway, S. R., \& McKinley, J. C. (1940). A multiphasic personality schedule (Minnesota): I. Construction of the schedule. The Journal of Psychology, 10(2), s. 249-254.

Hathaway, S.R. \& McKinley, J.C. (2002). [Autor české verze testu: Netík, K.] MMPI 2: Minnesota Multiphasic Personality Inventory-2. Praha: Testcentrum

Hogrefe-Testcentrum. (2016). MMPI®-2 - Minnesota Multiphasic Personality Inventory®-2. Dostupné online 27. 11. 2016 na http://www.testcentrum.com/testy/mmpi-2

Meehl, P. E., \& Hathaway, S. R. (1946). The K factor as a suppressor variable in the Minnesota Multiphasic Personality Inventory. Journal of Applied Psychology, 30(5), s. 525.

Netík, K. (2002). The Minnesota Multiphasic Personality Inventory - 2: první české vydání. Praha: Testcentrum

Obyvatelstvo ve věku 15 a více let podle nejvyššího ukončeného vzdělání ve správních obvodech ORP. (2016). [Online]. Retrieved March 11, 2017, from https://vdb.czso.cz/vdbvo2/faces/cs/index.jsf?page=vystup-objektvyhledavani\&vyhltext=vzd\%C4\%9B1\%C3\%A1n\%C3\%AD\&bkvt=dnpkxJtsw6Fuw60.\&katalog= all\&pvo=SLD9060PU-OR

Rogers, R., Sewell, K. W., \& Salekin, R. T. (1994). A Meta-Analysis of Malingering on the MMPI2. Assessment, 1(3), s. 227-237.

Rogers, R., Sewell, K. W., Harrison, K. S., \& Jordan, M. J. (2006). The MMPI-2 Restructured Clinical Scales: A Paradigmatic Shift in Scale Development. Journal of personality assessment, 87 (2), s. 139-147.

Sellbom, M. \& Ben-Porath (2005). Mapping the MMPI-2 Restructed Clilical Scales Onto Normal Personality Traits: Evidence of Construct Validity. Journal Of Personality Assessment, 85 (2).

Shkalim, E. (2015). Psychometric Evaluation of the MMPI-2/MMPI-2-RF Restructured Clinical Scales in an Israeli Sample. Assessment, 22 (5), s. 607-618. 
Stoklasa, J. (2012). Fuzzy prístup k vyhodnocování osobnostního inventáře MMPI-2 (Diplomová práce). Olomouc.

Tellegen, A., \& Ben-Porath, Y. S. (1992). The new uniform T scores for the MMPI-2: Rationale, derivation, and appraisal. Psychological Assessment, 4(2), s. 145.

Tellegen, A., Ben-Porath, Y. S., McNulty, J. L., Arbisi, P. A., Graham, J. R., \& Kaemmer, B. (2003). The MMPI-2 restructured clinical $(R C)$ scales: Development, validation, and interpretation. Minneapolis, MN: University of Minnesota Press.

Wang, J. J. (1992). An Analytical Approach to Generating Norms for Skewed Normative Distributions

\section{Měřené konstrukty:}

Standardní klinické škály:

Hypochondrie, deprese, konverzní hysterie, psychopatická odchylka, maskulinita-feminita, paranoia, psychastenie, schizofrenie, hypomanie, sociální introverze.

Validizační škály:

Ukazatel nekonzistentnost odpovědi, škála „nemohu říct“, F škála (ukazatel málo frekventovaných odpovědí), indikátory defenzivity (L škála a F škála), S škála (škála mimořádně pozitivní sebeprezentace) 